\title{
Fit-for-purpose based testing and validation of antibodies to amino- and carboxy-terminal domains of cannabinoid receptor 1
}

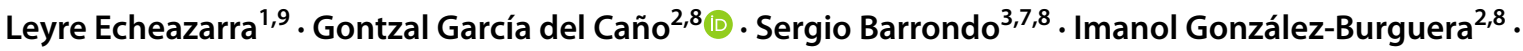 \\ Miquel Saumell-Esnaola ${ }^{3,8} \cdot$ Xabier Aretxabala ${ }^{2}$ Maider López de Jesús ${ }^{3,8} \cdot$ Leire Borrega-Román ${ }^{3,8}$. \\ Susana Mato ${ }^{4,10,11,12} \cdot$ Catherine Ledent $^{6} \cdot$ Carlos Matute $^{4,10,11} \cdot$ María Aranzazu Goicolea $^{5} \cdot$ Joan Sallés $^{3,7,8}$
}

Accepted: 17 August 2021 / Published online: 27 August 2021

(c) The Author(s) 2021

\begin{abstract}
Specific and selective anti- $\mathrm{CB}_{1}$ antibodies are among the most powerful research tools to unravel the complex biological processes mediated by the $\mathrm{CB}_{1}$ receptor in both physiological and pathological conditions. However, low performance of antibodies remains a major source of inconsistency between results from different laboratories. Using a variety of techniques, including some of the most commonly accepted ones for antibody specificity testing, we identified three of five commercial antibodies against different regions of $\mathrm{CB}_{1}$ receptor as the best choice for specific end-use purposes. Specifically, an antibody against a long fragment of the extracellular amino tail of $\mathrm{CB}_{1}$ receptor (but not one against a short sequence of the extreme amino-terminus) detected strong surface staining when applied to live cells, whereas two different antibodies against an identical fragment of the extreme carboxy-terminus of $\mathrm{CB}_{1}$ receptor (but not one against an upstream peptide) showed acceptable performance on all platforms, although they behaved differently in immunohistochemical assays depending on the tissue fixation procedure used and showed different specificity in Western blot assays, which made each of them particularly suitable for one of those techniques. Our results provide a framework to interpret past and future results derived from the use of different anti- $\mathrm{CB}_{1}$ antibodies in the context of current knowledge about the $\mathrm{CB}_{1}$ receptor at the molecular level, and highlight the need for an adequate validation for specific purposes, not only before antibodies are placed on the market, but also before the decision to discontinue them is made.
\end{abstract}

Keywords Antibody specificity $\cdot \mathrm{CB}_{1}$ receptor $\cdot$ Carboxy-terminus $\cdot$ Amino-terminus $\cdot$ Antigen retrieval $\cdot \mathrm{CB}_{1}$-knockout mice

Gontzal García del Caño

gontzal.garcia@ehu.eus

$\triangle$ Joan Sallés

joan.salles@ehu.eus

1 Departament of Physiology, Faculty of Pharmacy, University of the Basque Country UPV/EHU, Vitoria-Gasteiz, Spain

2 Department of Neurosciences, Faculty of Pharmacy, University of the Basque Country UPV/EHU, Vitoria-Gasteiz, Spain

3 Department of Pharmacology, Faculty of Pharmacy, University of the Basque Country UPV/EHU, Vitoria-Gasteiz, Spain

4 Department of Neurosciences, Faculty of Medicine and Nursing, University of the Basque Country UPV/EHU, Leioa, Spain

5 Department of Analytical Chemistry, Faculty of Pharmacy, University of the Basque Country UPV/EHU,

Vitoria-Gasteiz, Spain
6 6IRIBHN, Universite Libre de Bruxelles, Brussels, Belgium

7 Centro de Investigación Biomédica en Red de Salud Mental (CIBERSAM), 28029 Madrid, Spain

8 Bioaraba, Neurofarmacología Celular y Molecular, 01008 Vitoria-Gasteiz, Spain

9 Bioaraba, Dispositivos Móviles para el Control de Enfermedades Crónicas, 01008 Vitoria-Gasteiz, Spain

10 Centro de Investigación Biomédica en Red sobre Enfermedades Neurodegenerativas (CIBERNED), Madrid, Spain

11 Achucarro Basque Center for Neuroscience, Leioa, Spain

12 Multiple Sclerosis and Other Demyelinating Diseases Unit, Biocruces Bizkaia, Barakaldo, Spain 


\section{Introduction}

The endogenous cannabinoid system is composed of endogenous ligands (endocannabinoids), such as anandamide (AEA) and 2-arachidonoylglycerol (2-AG), the enzymes responsible for their turnover and the inhibitory G-protein-coupled receptors (GPCRs) $\mathrm{CB}_{1}$ and $\mathrm{CB}_{2}$ (Piomelli 2003; Kano et al. 2009). $\mathrm{CB}_{1}$ receptor is the most abundant GPCR in the central nervous system (Herkenham 1991; Piomelli 2003) and is densely expressed in brain (Herkenham 1991; Mailleux and Vanderhaeghen 1992; Matsuda et al. 1993; Dove Pettit et al. 1998; Tsou et al. 1998; Marsicano and Lutz 1999; Egertová and Elphick 2000; Howlett et al. 2002; McPartland et al. 2007). It is now known that brain $\mathrm{CB}_{1}$ receptor plays key roles in regulating a variety of behavioural responses and primary physiological processes, such as memory and cognitive processes, motor activity, pain perception, temperature regulation, feeding behaviour, energy balance and stress responses (Maldonado et al. 2020), while dysregulation of $\mathrm{CB}_{1}$ receptor-mediated signalling underlies a plethora of pathological conditions, including neuropsychiatric and neurodegenerative diseases among others (Cristino et al. 2020). Thus, $\mathrm{CB}_{1}$ receptor has emerged as a promising therapeutic target for a variety of diseases (Chicca et al. 2017; Di Marzo 2018; Cristino et al. 2020; FernándezRuiz et al. 2020), and consequently, research towards the development of synthetic $\mathrm{CB}_{1}$ and natural ligands as potential therapeutic drugs for brain disorders underwent a rapid expansion (An et al. 2020; Cinar et al. 2020), in parallel with a growing effort of basic scientists towards unravelling the complex molecular mechanisms of $\mathrm{CB}_{1}$ receptor-mediated signalling. The expression of brain $\mathrm{CB}_{1}$ receptors in a variety of cell phenotypes and subcellular compartments, the pleiotropic effects of exogenous $\mathrm{CB}_{1}$ receptor ligands and the dynamic processes governing $\mathrm{CB}_{1}$ receptor trafficking (Busquets-Garcia et al. 2018) constitute additional sources of complexity that require the use of reliable research tools, of which specific and selective anti-CB ${ }_{1}$ antibodies are among the most powerful ones.

An important caveat for the use of antibodies is that they may provide poorly reproducible and inaccurate results, and therefore, antibody testing and validation are essential before being used in research. Development of reliable antibodies against GPCRs is especially challenging (Saper 2005; Jositsch et al. 2009; Kirkpatrick 2009; Talmont et al. 2012; Baker 2015), and serious doubts had been raised about the usefulness of a variety of anti-GPCR antibodies (O'Connell et al. 2006; Rhodes and Trimmer 2006; Pradidarcheep et al. 2008; Jositsch et al. 2009; Michel et al. 2009). Obviously, all these caveats are equally applicable to antibodies against $\mathrm{CB}_{1}$ receptor, and proper validation is a fundamental pre-requisite before studies using these antibodies are conducted. However, there are only two research papers devoted entirely to the study of the specificity of anti-CB $\mathrm{CB}_{1}$ antibodies. In one of these studies (Grimsey et al. 2008), five antibodies generated against different sequences of the amino- and carboxy-tails of the $\mathrm{CB}_{1}$ receptor were tested for specificity by immunohistochemistry, in tissue sections of mouse brain and transfected HEK cells, and by Western blot, in transfected cells and brain lysates. The authors reported good results for two antibodies developed by Ken Mackie's research group (Hájos et al. 2000; Wager-Miller et al. 2002) against carboxy-terminal (C-terminal) cytosolic regions of the $\mathrm{CB}_{1}$ receptor, but poor specificity for three commercial antibodies against amino-terminal (N-terminal) extracellular regions of $\mathrm{CB}_{1}$ receptor in all end uses assayed. In a more recent study using two commercial $\mathrm{N}$-terminal and two C-terminal antibodies, authors focused on establishing the appropriate conditions for Western blot detection and immunoprecipitation of $\mathrm{CB}_{1}$ receptor in samples from brain and cortical neuron cultures (Esteban et al. 2020). This study emphasized the importance of temperature and detergents for the final result and proposed a new interpretation of Western blot and immunoprecipitation data based on the folding and packing state of $\mathrm{CB}_{1}$ and the detergent used.

Notably, antibody testing and validation must consider their end-use application, and a recently proposed guide for antibody validation included explicit recommendations on the suitability experimental approaches for such a purpose (Uhlen et al. 2016). Circumventing this aspect can lead companies to discontinue production of antibodies that would otherwise be very useful for a given platform, and indeed, several companies have incorporated the fit-for-purpose (F4P) concept for antibody development (Voskuil 2014). Here we performed a F4P-based analysis of the specificity of five representative commercial anti$\mathrm{CB}_{1}$ antibodies designed against $\mathrm{N}$ - and $\mathrm{C}$-terminal regions of $\mathrm{CB} 1$ receptor (hereinafter referred to as $\mathrm{N}$ - and $\mathrm{C}$-terminal antibodies) and selected on the basis of the sequences against which they were generated, which can determine the final outcome in different end-use applications. This included two $\mathrm{N}$-terminal and one $\mathrm{C}$-terminal antibodies from Santa Cruz Biotechnology, which have been discontinued and replaced by other antibodies probably due to low demand, and two polyclonal antibodies raised in goat and rabbit against the 31 amino acids at the extreme carboxy-terminus (C-terminus) of $\mathrm{CB}_{1}$ receptor, which have been widely used in the last decade (Yoneda et al. 2013; Rivera et al. 2015; Rodríguez-Cueto et al. 2016; Mateo et al. 2017; Puighermanal et al. 2017; Rhomberg et al. 2018; Diniz et al. 2019; Puente et al. 2019; Uchigashima et al. 2020; Exposito-Alonso et al. 2020; Peñasco et al. 
2020; Egaña-Huguet et al. 2021; Fuerte-Hortigón et al. 2021) and validated for some applications using different transgenic mice models lacking $\mathrm{CB}_{1}$ receptor, either completely or in specific cell phenotypes or subcellular compartments (Hebert-Chatelain et al. 2014a; Remmers et al. 2017; Gutiérrez-Rodríguez et al. 2018). To this end, our workflow combined commonly accepted testing and validation approaches along with pharmacological assays to confirm or rule out the presence of $\mathrm{CB}_{1}$ receptor in samples yielding $\mathrm{CB}_{1}$-like immunoreactive bands on Western blot. Of the five antibodies analysed, only the two raised against the extreme $\mathrm{C}$-terminus of $\mathrm{CB}_{1}$ were suitable for detection of $\mathrm{CB}_{1}$ receptor in all the applications tested. However, although the other three antibodies analysed were unable to detect $\mathrm{CB}_{1}$ receptor by Western blot and by immunohistochemistry in tissue sections, two of them recognized $\mathrm{CB}_{1}$ receptor in $\mathrm{CB}_{1}$-transfected cells HEK-293 cells, and moreover, one of them raised against a large fragment of the extracellular N-terminal region of $\mathrm{CB}_{1}$ receptor yielded strong specific immunofluorescence at the plasma membrane under non-permeabilizing conditions in live cells. Our results provide robust data on the suitability for different applications of the anti- $\mathrm{CB}_{1}$ antibodies tested, and highlight the importance of choosing the platform that best fits the end use of a given antibody before discarding it for any use on the basis of an inaccurate validation approach.

\section{Materials and methods}

\section{Animals}

Sprague-Dawley rats were obtained from SGIker facilities (University of the Basque Country, UPV/EHU, Spain). $\mathrm{CB}_{1}$ receptor null mutant $\left(\mathrm{CB}_{1}-\mathrm{KO}\right)$ and wild-type $\left(\mathrm{CB}_{1}-\mathrm{WT}\right)$ mice were either bred from the Spanish colony established at the University of the Basque Country (Ledent's $\mathrm{CB}_{1}-\mathrm{KO}$ mice) or kindly provided by Dr. Giovanni Marsicano (Institute François Magendie, Bordeaux, France) (Marsicano's $\mathrm{CB}_{1}-\mathrm{KO}$ mice) and genotyped as described before (Ledent et al. 1999; Marsicano et al. 2002). Both mice and rats were kept in a controlled environment $(12 \mathrm{~h}$ light-dark cycle, $22 \pm 2{ }^{\circ} \mathrm{C}$ and $55 \pm 5 \%$ relative humidity) with food and water provided ad libitum, for at least 7 days until they were sacrificed at 10-12 weeks of age. All experiments involving animals were approved by the Committee of Ethics for Animal Welfare of the University of the Basque Country (UPV/EHU; CEBA/146/2010 and CEBA/61/2010) and performed following guidelines of the Directive of the European Commission (2010/63/EU) and
Spanish regulations (RD 53/2013) for care and management of experimental animals.

\section{Perfusion and preparation of tissue sections for immunohistochemistry}

Six adult Sprague-Dawley rats, four adult mice from the Ledent's line ( $2 \mathrm{CB}_{1}$-WT and $\left.2 \mathrm{CB}_{1}-\mathrm{KO}\right)$ and four adult mice from the Marsicano's line $\left(2 \mathrm{CB}_{1}-\mathrm{WT}\right.$ and $\left.2 \mathrm{CB}_{1}-\mathrm{KO}\right)$ were used for immunohistochemistry. Animals were anaesthetized intraperitoneally with an overdose of choral hydrate $(1 \mathrm{~g} / \mathrm{kg}$ i.p.; Panreac Química S.A., Castellar del Vallés, Barcelona, Spain) before perfusion. Rats were transcardially perfused with either $0.1 \mathrm{M}$ phosphate-buffered saline $\mathrm{pH} 7.4$ (PBS) or a $0.37 \%(\mathrm{w} / \mathrm{v})$ sulphide solution (three animals each) for $4 \mathrm{~min}$, followed by $4 \%$ (w/v) paraformaldehyde (Sigma, St. Louis, MO, USA) in $0.1 \mathrm{M}$ phosphate buffer for $4 \mathrm{~min}$ at a constant flow of $30 \mathrm{ml} / \mathrm{min}$ (Heidolph Instruments $\mathrm{GmbH}$ \& Co. KG, Pumpdrive PD 5106, Schwabach, Germany). All four $\mathrm{CB}_{1}-\mathrm{WT}$ and $\mathrm{CB}_{1}-\mathrm{KO}$ mice were transcardially perfused with a $0.37 \%(\mathrm{w} / \mathrm{v})$ sulphide solution for $4 \mathrm{~min}$, followed by $4 \%(\mathrm{w} / \mathrm{v})$ paraformaldehyde for $4 \mathrm{~min}$ at a constant flow of $10 \mathrm{ml} / \mathrm{min}$. After that, brains were removed and kept immersed in the same fixative medium during $4 \mathrm{~h}$. Next, brains were transferred to phosphate buffer $0.1 \mathrm{M}, \mathrm{pH} 7.4$ (PB) containing 30\% sucrose and kept at $4{ }^{\circ} \mathrm{C}$ and constant stirring until they sank. Brains were cryosectioned using a microtome (Leitz-Wetzlar 1310, Wetzlar, Germany) provided with a specific sensor to control temperature (5MP BFS-Physitemp Controller, Clifton, New Jersey, USA). Twelve (rats) or six (mice) separate representative series of free-floating $40-\mu \mathrm{m}$-thick coronal sections were obtained from each brain and collected in PBS. Sections were cryoprotected by incubations in increasing concentrations (5\%, $10 \%$ and $20 \% \mathrm{v} / \mathrm{v}$ ) of dimethyl sulphoxide (Sigma, St. Louis, MO, USA) in PB. Section series were then separately placed in the bottom of Eppendorf tubes, subjected to a permeabilization protocol, consisting of three freeze-thaw cycles in isopentane at $-80{ }^{\circ} \mathrm{C}$, and stored frozen until use.

\section{Cell culture and transfection of HEK-293 cells}

Human embryonic kidney 293 (HEK-293) from the American Type Culture Collection (ATCC; CRL-1573 ${ }^{\mathrm{TM}}$ ) were grown in $75 \mathrm{~cm}^{2}$ cell culture flasks $(430,725$; Corning, Barcelona, Spain) in DMEM culture medium (ATCC, 30-2002), supplemented with $10 \%$ fetal bovine serum (Sigma-Aldrich) and antibiotics $(100 \mathrm{U} / \mathrm{mL}$ penicillin and $100 \mu \mathrm{g} / \mathrm{mL}$ streptomycin, Gibco, Life Technologies S.A., Madrid, Spain). When approaching 70-80\% confluence, cells were harvested using trypsin-EDTA solution (25,300-054, Gibco, Barcelona, Spain) and transferred to 12 -well plates containing poly-D-lysine coated glass 
coverslips. When they reached $70-80 \%$ confluence, cells were transfected with pcDNA3.0 plasmid containing a cDNA insert encoding the human cannabinoid receptor 1 (pCDNA-CB ${ }_{1} ; 1 \mu \mathrm{g}$ DNA/well) using Lipofectamine 3000 (L3000001; Invitrogen S.A., Spain). Cells were processed for single or double immunofluorescence $48 \mathrm{~h}$ after transfection.

\section{Isolation of enriched subcellular fractions}

A total of ten adult Sprague-Dawley rats and ten adult mice from the Ledent's line $\left(5 \mathrm{CB}_{1}-\mathrm{WT}\right.$ and $\left.5 \mathrm{CB}_{1}-\mathrm{KO}\right)$ were used for isolation of subcellular fractions intended to be used in Western blot and pharmacological assays. After sacrificing animals by decapitation, brains were immediately removed and cerebral cortices were dissected out on ice and stored at $-80{ }^{\circ} \mathrm{C}$. P1, P2 and cytosolic (Cyt) subcellular fractions from five rat and four mouse $\left(5 \mathrm{CB}_{1}-\mathrm{WT}\right.$ and $5 \mathrm{CB}_{1}-\mathrm{KO}$ ) cerebral cortex samples were obtained essentially as previously described for rat and human brain tissues (Garro et al. 2001; Sallés et al. 2001; Montaña et al. 2012; García del Caño et al. 2015). To isolate highly purified intact nuclei ( $\mathrm{N}$ fraction) used for both immunofluorescence and Western blot, we followed the procedure described by Thompson and colleagues (Thompson 1973) with slight modifications (Montaña et al. 2012; García del Caño et al. 2015) (Supplementary Material and Methods for details).

\section{Immunohistochemistry and double immunofluorescence}

Brain sections were incubated free-floating with the same amount of freshly prepared reaction solutions in all cases. Sections were treated for 20 min with $1 \% \mathrm{H}_{2} \mathrm{O}_{2}$ in phosphate-buffered saline $0.1 \mathrm{M}, \mathrm{pH} 7.4$ (PBS) to inactivate endogenous peroxidase. Thereafter, they were incubated at $20-25{ }^{\circ} \mathrm{C}$ for $1 \mathrm{~h}$ in blocking solution, consisting of PBS containing 1\% serum albumin bovine (BSA; Sigma, St. Louis, MO, USA) and 1\% normal goat or rabbit serum (Vector Laboratories, Burlingame, CA, USA) for anti$\mathrm{CB}_{1}$ antibodies raised in rabbit (H150 and Af380) or goat (N15, K15 and Af450), respectively (see details for anti$\mathrm{CB}_{1}$ receptor antibodies in Table 1). Subsequently, tissue sections were incubated overnight at $4{ }^{\circ} \mathrm{C}$ in the corresponding anti-CB $\mathrm{CB}_{1}$ primary antibody diluted in blocking solution. Sections were then incubated for $1 \mathrm{~h}$ at $20-25^{\circ} \mathrm{C}$ with affinity-purified biotinylated secondary antibodies goat anti-rabbit (BA-1000; Vector Laboratories) or rabbit anti-goat (BA-5000; Vector Laboratories), both diluted 1:200 in blocking solution. Sections were then processed by the avidin-biotin-peroxidase method using the Vectastain kit (Vector Laboratories) and reacted with $0.05 \%$ 3,3'-diaminobenzidine tetrahydrochloride and $0.01 \% \mathrm{H}_{2} \mathrm{O}_{2}$ in $50 \mathrm{mM}$ Tris- $\mathrm{HCl}, \mathrm{pH}$ 7.6. Finally, the sections were mounted onto gelatine-coated slides, air-dried, dehydrated and coverslipped using DPX (Fluka, Buchs, Switzerland).

Table 1 Anti-CB $\mathrm{CB}_{1}$ receptor primary antibodies

\begin{tabular}{|c|c|c|c|c|c|c|}
\hline Short name & Dilution (IHC/IF) & Dilution (WB) & Host and clonality & Isotype and purity & Immunizing antigen & Source, cat. no. \\
\hline N15 & $1: 100$ & $1: 500$ & Goat polyclonal & Affinity-purified IgG & $\begin{array}{l}\text { Peptide derived from } \\
\text { within residues 1-50 } \\
\text { of the human } \mathrm{CB}_{1} \\
\text { receptor }\end{array}$ & $\begin{array}{l}\text { Santa Cruz Biotech., } \\
\text { CB1 (N-15): sc-10066 }\end{array}$ \\
\hline $\mathrm{H} 150$ & $1: 200$ & $1: 250$ & Rabbit polyclonal & Affinity-purified IgG & $\begin{array}{l}\text { Peptide correspond- } \\
\text { ing to amino acids } \\
1-150 \text { of human } \mathrm{CB}_{1} \\
\text { receptor }\end{array}$ & $\begin{array}{l}\text { Santa Cruz Biotech., } \\
\text { CB1 (H-150): sc-20754 }\end{array}$ \\
\hline K15 & $1: 200$ & $1: 250$ & Goat polyclonal & Affinity-purified IgG & $\begin{array}{l}\text { Peptide sequence } \\
\text { from within residues } \\
397-447 \text { of the } \\
\text { human } \mathrm{CB}_{1} \text { receptor }\end{array}$ & $\begin{array}{l}\text { Santa Cruz Biotech., } \\
\text { CB1 (K-15): sc-10068 }\end{array}$ \\
\hline Af380 & $1: 200$ & $1: 1000$ & Rabbit polyclonal & $\begin{array}{l}\text { Immunogen affinity- } \\
\text { purified IgG }\end{array}$ & $\begin{array}{l}\text { Peptide corresponding } \\
\text { to the carboxy-termi- } \\
\text { nal } 31 \text { amino acids of } \\
\text { mouse CB1 receptor }\end{array}$ & $\begin{array}{l}\text { Frontier Institute Co., } \\
\text { Ltd., } \\
\text { CB1-Rb-Af380 }\end{array}$ \\
\hline Af450 & $1: 200$ & $1: 500$ & Goat polyclonal & $\begin{array}{l}\text { Immunogen affinity- } \\
\text { purified IgG }\end{array}$ & $\begin{array}{l}\text { Peptide corresponding } \\
\text { to the carboxy-termi- } \\
\text { nal } 31 \text { amino acids of } \\
\text { mouse } \mathrm{CB}_{1} \text { receptor }\end{array}$ & $\begin{array}{l}\text { Frontier Institute Co., } \\
\text { Ltd., } \\
\text { CB1-Go-Af450 }\end{array}$ \\
\hline
\end{tabular}

Antibody manufacturers: Santa Cruz Biotechnology, Santa Cruz, CA, USA; Frontier Science Co. Ltd., Hokkaido, Japan $I H C$ immunohistochemistry, $I F$ immunofluorescence, $W B$ Western blot 
For double immunofluorescence in tissue, sections were preincubated at $20-25{ }^{\circ} \mathrm{C}$ for $1 \mathrm{~h}$ in blocking solution, consisting of $1 \%$ serum albumin bovine (BSA; Sigma, St. Louis, MO, USA) and 1\% normal donkey serum (Jackson Immunoresearch Laboratories, Inc.; West Grove, PA, USA), followed by overnight incubation at $4{ }^{\circ} \mathrm{C}$ with a combination of

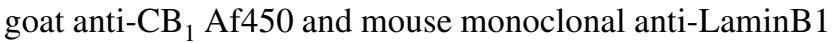
(sc-56144; Santa Cruz Biotechnology) primary antibodies, diluted in blocking solution, both at a final concentration of $2 \mu \mathrm{g} / \mathrm{ml}$. Thereafter, sections were incubated at $20-25{ }^{\circ} \mathrm{C}$ temperature for $1 \mathrm{~h}$ in Alexa Fluor 488 donkey anti-goat IgG (A11055; Invitrogen S.A.) and DyLight 549 donkey anti-mouse $\mathrm{F}\left(\mathrm{ab}^{\prime}\right) 2$ fragment (715-506-151; Jackson Immunoresearch Laboratories, Inc.) both diluted 1:400 in blocking solution. Finally, sections were mounted onto gelatinecoated slides with Mowiol reagent (Calbiochem, Bad Soden am Taunus, Germany). When the immunizing peptide was available (N15, K15, Af380 and Af450), negative controls were performed by using antibodies preabsorbed overnight at $4{ }^{\circ} \mathrm{C}$ with excess immunizing antigen (IgG-to-peptide mass ratios 1:5 in all cases).

Cells processed for single or double immunofluorescence against $\mathrm{CB}_{1}$ receptor under permeabilizing conditions were fixed for $10 \mathrm{~min}$ at $20-25{ }^{\circ} \mathrm{C}$ with $4 \%$ phosphate-buffered paraformaldehyde, washed extensively with wash buffer (PBS containing $0.22 \%$ gelatine) and incubated with permeabilizing blocking buffer (PERM; wash buffer containing $0.066 \%$ saponin, $1 \%$ bovine serum albumin, $1 \%$ normal donkey serum) for $1 \mathrm{~h}$ at $20-25^{\circ} \mathrm{C}$. Thereafter, cells were incubated overnight at $4{ }^{\circ} \mathrm{C}$ with rabbit (H150 and Af380) or goat (N15, K15 and Af450) anti-CB 1 primary antisera (see Table 1 for details), either alone (for single immunofluorescence) or in the following combinations (for double immunofluorescence): Af380/N15 Af450/H150, Af380/K15 or Af450/Af380. To test the ability of N-terminal antibodies to detect surface $\mathrm{CB}_{1}$ receptor in live HEK-293 cells, culture medium was replaced with cold serum-free OptiMEM (51,985-034; Life Technologies, Barcelona, Spain), and goat N15 or rabbit $\mathrm{H} 150$ antibodies were added directly to cell cultures, followed by incubation for $30 \mathrm{~min}$ at $4{ }^{\circ} \mathrm{C}$. After three washes with cold PBS, cells were fixed, washed and blocked as above and incubated overnight at $4{ }^{\circ} \mathrm{C}$ with Af380 or Af450 antibodies, respectively. After three washes (10 min each) at $20-25{ }^{\circ} \mathrm{C}$ with washing buffer, cells were incubated with the appropriate fluorescent dye-conjugated secondary antibodies diluted 1:400 in PERM, for $1 \mathrm{~h}$ at 20-25 ${ }^{\circ} \mathrm{C}$. Thus, Dylight 549 Donkey anti-Rabbit F(ab')2 fragment (711-506-152, Jackson Immunoresearch Laboratories, Inc.; West Grove, PA, USA, ) and Alexa Fluor 488 Donkey anti-Goat IgG (A-11055; Invitrogen S.A.) were used either alone, for single immunofluorescence, or combined, for double immunofluorescence. After the secondary antibody incubation, cells were washed twice with wash buffer for $10 \mathrm{~min}$ at $20-25^{\circ} \mathrm{C}$, and cell nuclei were counterstained with $0.1 \mu \mathrm{g} / \mathrm{mL}$ Hoechst 33,342 (Sigma-Aldrich) in wash buffer, for $10 \mathrm{~min}$ at $20-25{ }^{\circ} \mathrm{C}$. After two additional washes (10 min each) at $20-25{ }^{\circ} \mathrm{C}$ with PBS, cells were mounted onto glass slides using homemade Mowiol (Calbiochem, Madrid, Spain) mounting medium, containing anti-fade reagent 1,4-phenylene-diamine dihydrochloride (Sigma-Aldrich).

Double immunofluorescence in intact nuclei with anti$\mathrm{CB}_{1}$ Af450 antibody combined with mouse monoclonal antibodies to the nuclear components Lamin-B1, Histone H1, NeuN-Fox-3 or SC35 (see Table S1 for details) was performed as described for fixed HEK-293 cells, except that Alexa Fluor 488 donkey anti-goat IgG (A-11055; Invitrogen S.A.) and DyLight 549 donkey anti-mouse $\mathrm{F}\left(\mathrm{ab}^{\prime}\right) 2$ fragment (715-506-151; Jackson Immunoresearch Laboratories, Inc.) were used as secondary antibodies.

To establish dilutions of the primary antibodies used in the immunohistochemistry and double immunofluorescence experiments (Table 1), preliminary tests were carried out at three dilutions in transfected HEK-293 cells and the one that provided the best signal-to-noise ratio was chosen. The concentrations tested for all antibodies were 1: 100, 1: 200 and 1: 400, which were based on the range recommended by the manufacturer in the case of Santa Cruz antibodies N15, H150 and K15 (1: 50-1: 500) and on the data available in the literature in the case of Frontier antibodies. Institute Co. Af380 and Af450.

\section{Microscope imaging and co-localization analysis}

Immunostained brain sections were examined with an Olympus BX50F optic microscope (Olympus, Tokyo, Japan) equipped with a high-resolution digital camera (Olympus and Soft Imaging Systems, Tokyo, Japan). Images were digitized using CellA software for image acquisition with automatic or manual exposure control (Olympus and Soft Imaging Systems, Tokyo, Japan). Images of double immunofluorescence-stained tissue sections were captured sequentially on an Olympus Fluoview FV500 confocal microscope (Olympus, Tokyo, Japan) equipped with a diode laser line of $405 \mathrm{~nm}$, an Argon laser line of 457, 488 and $514 \mathrm{~nm}$, and HeNe laser line of $543 \mathrm{~nm}$ and $633 \mathrm{~nm}$. Alexa Fluor 488 was viewed using 505/525 nm BP filters and Alexa Fluor 568 using 560-600 nm BP filters. Images were acquired using a pinhole of one airy unit and objective $60 \times(1.40$ NA, Plan Apochromat). Viewing of $Z$-stacks and minor despeckling was performed on the Fluoview Image Browser software, version 5.0 (Olympus, Tokyo, Japan). Images were subsequently exported to TIFF format. Boundaries of cortical layers were determined on the basis of variations in the intensity of the immunohistochemical reaction and Nissl 
staining distribution in neighbouring sections. All figures were compiled and labelled using Adobe Photoshop CS3.

Fluorescence imaging of $\mathrm{CB}_{1}$-transfected HEK-293 cells was performed on a Carl Zeiss Axio Observer.Z1 epifluorescence microscope (Carl Zeiss MicroImaging, Inc, Gottigen, Germany), equipped with a HXP $120 \mathrm{C}$ metal halide light source. Micrographs were acquired using a AxioCam MRm $(1388 \times 1040$ pixels) monochromatic camera (Carl Zeiss MicroImaging, Inc.) and a $63 \times$ Plan-Apochromat objective (NA 1.4) with exposure time set to levels just below saturation for each dye. The ApoTome structured illumination module and a computer-controlled $X Y Z$ motorized stage (both from Carl Zeiss MicroImaging, Inc.) were used to obtain optical sections in the $Z$-axis, with camera settings adjusted to obtain images with a pixel size of $0.01 \mu \mathrm{m}^{2}$. Bandpass filters used were 49 DAPI (Ex G 365/Em 445/50) for Hoechst's staining, $38 \mathrm{HE}$ eGFP (Ex 470/40, Em 525/50) for Alexa Fluor 488, and $43 \mathrm{HE} \mathrm{Cy3}$ shift free (Ex 550/25, Em 605/70) for DyLight 549. Images were digitized using Zeiss Axio Vision 4.8 software (Carl Zeiss MicroImaging, Inc). Minor despeckling was performed on ImageJ (NIH, Bethesda, MD, USA) software. Images were exported to TIFF format, and compiled and labelled using Adobe Photoshop CS3 (San Jose, CA, USA).

Co-localization analysis was performed on 10-14 representative images for each of the four antibody combinations (Af380/N15, $n=10$; Af450/H150, $n=11$; Af380/K15, $n=14$; Af380/Af450, $n=11$ ) from at least two independent experiments. To calculate Mander's overlap (M1 and M2) and Pearson's intensity correlation $\left(R_{P}\right)$ coefficients, all $Z$-stacks acquired from the top to the bottom of cells at $0.24 \mu \mathrm{m}$ intervals were analysed using JACoP plugin (Bolte and Cordelières, 2006) in Fiji-ImageJ Software (National Institute of Health, Bethesda, MA, USA). A Kruskal-Wallis analysis of variance was used to identify statistically significant differences in Mander's and Pearson's coefficients among the four antibody combinations. Dunn's multiple comparison post hoc test was used to find significant differences between selected pairs of antibody combinations. The level of significance was set at $P<0.05$ for both analyses.

\section{Western blotting}

Western blot studies were performed as previously reported with minor modifications (Garro et al., 2001; López de Jesús et al., 2006; Ruiz de Azúa et al. 2006). Briefly, known amounts of total protein from $\mathrm{P} 1, \mathrm{P} 2$, Cyt or $\mathrm{N}$ fractions were heated for $5 \mathrm{~min}$ at $60{ }^{\circ} \mathrm{C}$ in urea-denaturing buffer (20 mM Tris-HCl, pH 8.0, 12\% glycerol, 12\% urea, 5\% dithiothreitol, $2 \%$ sodium dodecyl sulphate, $0.01 \%$ bromophenol blue) and resolved by electrophoresis in 5-12\% gradient SDS-polyacrylamide gels (SDS-PAGE) using the Mini Protean II gel apparatus (Bio-Rad; Hercules, CA, USA).
Proteins were transferred to polyvinylidene fluoride (PVDF) membranes (Amersham Biosciences, Piscataway, NJ, USA), using the Mini TransBlot transfer unit (Bio-Rad; Hercules, CA, USA) at $30 \mathrm{~V}$ constant overnight at $4{ }^{\circ} \mathrm{C}$ and processed for immunoblot analysis (see Supplementary Material and Methods for details).

\section{Binding assays}

Radioligand binding assays were carried out as previously described with minor modifications (López-Rodríguez et al. 2002; Barrondo and Sallés 2009; Casadó et al. 2010). The affinity $\left(K_{D}\right)$ and the maximal number of sites $\left(B_{\max }\right)$ for the selective $\mathrm{CB}_{1}$ receptor antagonist $\left[{ }^{3} \mathrm{H}\right] \mathrm{SR} 141716 \mathrm{~A}$ were measured by saturation binding experiments in P1, P2 and $\mathrm{N}$ subcellular fractions of the adult rat brain cortex (see Supplementary Material and Methods for details). For assays of $\left[{ }^{35} \mathrm{~S}\right] \mathrm{GTP} \gamma \mathrm{S}$ binding stimulated by increasing concentrations of the $\mathrm{CB}_{1}$ receptor agonist WIN 55,212-2, we followed the procedure described elsewhere for human and rat brain membranes (González-Maeso et al. 2000; Barrondo and Sallés, 2009) to obtain the efficacy $\left(E_{\max }\right)$ and potency $\left(E C_{50}\right)$ values.

Radioligand and $\left[{ }^{35} \mathrm{~S}\right] \mathrm{GTP} \gamma \mathrm{S}$ binding assays were performed in triplicate and duplicate, respectively, and the results were obtained from at least three independent experiments. Data are expressed as mean \pm SEM. Experimental data were analysed using computerized iterative procedure (GraphPad Prism version 4.0) by directly fitting the data to the suitable mathematical models, as described previously (Barrondo and Sallés 2009; Casadó et al. 2010). For the statistical significance (set at $P<0.05$ ) of the differences between affinity and potency constant values, these parameters were logarithmically transformed because it has been demonstrated that parameters like affinity and $\mathrm{EC}_{50}$ constants obtained experimentally are log-normally distributed, and, therefore, statistical analysis should be performed as such (Christopoulos 1998) (see Supplementary Material and Methods for further details).

\section{Results}

Five commercial antibodies designed against different sequences of the $\mathrm{CB}_{1}$ receptor highly conserved across human mouse and rat were assayed for specificity. Goat polyclonal antibodies N15 and H150 were designed against two different sequences of the N-terminal region of the human $\mathrm{CB}_{1}$ receptor. Rabbit polyclonal antibody K15 was raised against an internal sequence near the $\mathrm{C}$-terminus of $\mathrm{CB}_{1}$ receptor. Af380 and Af450 antibodies were both raised against the C-terminal 31 amino acids of $\mathrm{CB}_{1}$ receptor, and produced in rabbit and goat, respectively (Fig. 1; Table 1). 


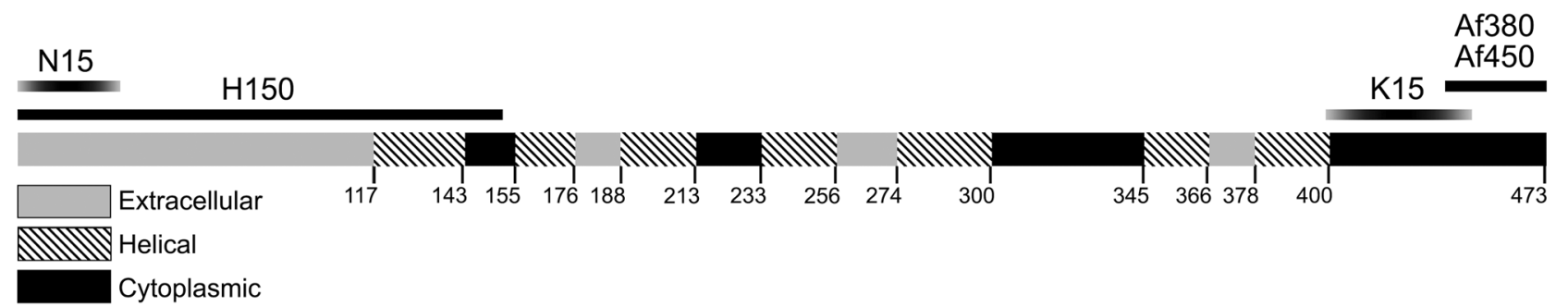

$\mathrm{N} 15$

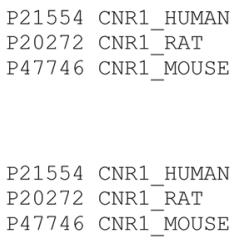

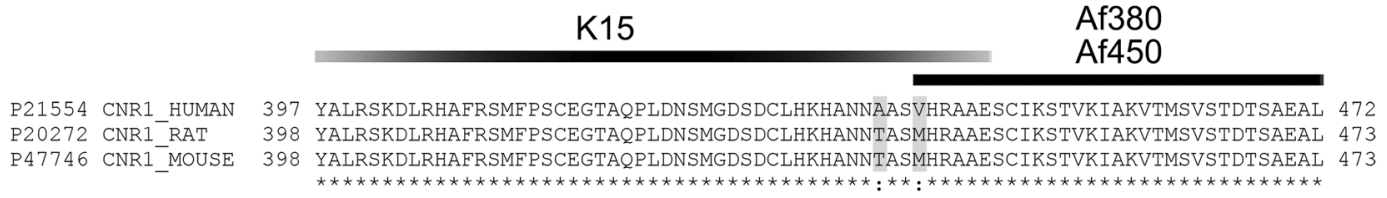

Fig. 1 Linear scale representation of the sequence of the rat $\mathrm{CB}_{1}$ receptor (Uniprot ID P20272; available at http://www.uniprot.org/) and amino acid sequence alignment of human, rat and mouse $\mathrm{CB}_{1}$ receptor using UniProt Align (https://www.uniprot.org/align/). The position of the antigenic sequences used to produce the anti-CB $\mathrm{CB}_{1}$ rabbit (H150, Af380) and goat (N15, K15, Af450) polyclonal antibod-

The ability of antibodies to specifically bind their target antigen was first tested by immunofluorescence in paraformaldehyde fixed and permeabilized HEK-293 cells transiently transfected with an expression plasmid encoding for the fulllength human $\mathrm{CB}_{1}$ receptor. Under these conditions, all the five anti- $\mathrm{CB}_{1}$ antibodies clearly detected $\mathrm{CB}_{1}$-transfected cells, although N15 and K15 antibodies required longer exposure times to capture immunofluorescence signals to the point just below saturation, and N15 antibody produced a diffuse background staining in non-transfected cells. Intense intracellular immunostaining was seen with all five antibodies, whereas plasma membrane staining was more variable (Fig. 2). As a more accurate indicator of the variable ability of the different antibodies to recognize their target antigens in $\mathrm{CB}_{1}$ overexpressing HEK-293 cells, we combined anti- $\mathrm{CB}_{1}$ antibodies raised in different species for double immunofluorescence in fixed and permeabilized cells. As expected for couples of antibodies against the same target protein, all combinations resulted in double staining of $\mathrm{CB}_{1}$ receptor-transfected cells, but with differences in the extent of co-localization. Thus, stainings produced by N15 and Af380 antibodies were highly co-localized in the cytoplasm surrounding the cell nucleus but not in the periphery of the cell, including the plasma membrane, where Af450 ies tested are indicated in both (see Table 1 for further details on anti- $\mathrm{CB}_{1}$ antibodies). Numbers on the linear representation of $\mathrm{CB}_{1}$ receptor refer to the amino acid residues in the sequence. Asterisks, two dots and one dot below the sequence alignment indicate fully conserved, highly conserved and weakly conserved residues across human, rat and mouse.

antibody produced a considerably stronger immunoreactivity than N15 (Fig. 2a-c). Combination of antibody couples H150/Af450 (Fig. 3d-f) and Af380/Af450 (Fig. 3j-1) led to an almost complete co-localization throughout the entire cell, whereas K15/Af380 combination produced a reddishcoloured plasma membrane in merged images as a consequence of a considerably weaker surface labelling with K15 antibody compared with Af450 (Fig. 3g-i). These findings were quantitatively analysed by measuring the percent pixel overlap (Mander's $M 1$ and $M 2$ coefficients) and the pixel intensity correlation (Pearson's $R_{P}$ coefficient) between the two immunofluorescence signals of doubly immunostained cells. Kruskal-Wallis ANOVA revealed statistically significant differences for both $M 1(P<0.005)$ and $M 2$ coefficients $(P<0.0001)$, whereas Dunn's multiple comparison test found significant differences between selected pairs of antibody combinations (Fig. $3 \mathrm{~m}$ ). Thus, according to qualitative observations, both $M 1$ and $M 2$ coefficients were close to 1.0 for the Af450/Af380 combination $(M 1,0.94 \pm 0.04 \mathrm{SD}$, $M 2,0.93 \pm 0.04 \mathrm{SD}$ ) and slightly lower, but not statistically different, for the Af450/H150 combination $(M 1,0.87 \pm 0.10$ $\mathrm{SD} ; M 2,0.89 \pm 0.05 \mathrm{SD})$. Lower Mander's coefficients, particularly $M 2$, were obtained for the Af380/K15 pair ( $M 1$, $0.85 \pm 0.09 \mathrm{SD} ; M 2,0.79 \pm 0.11 \mathrm{SD})$, reaching statistically 

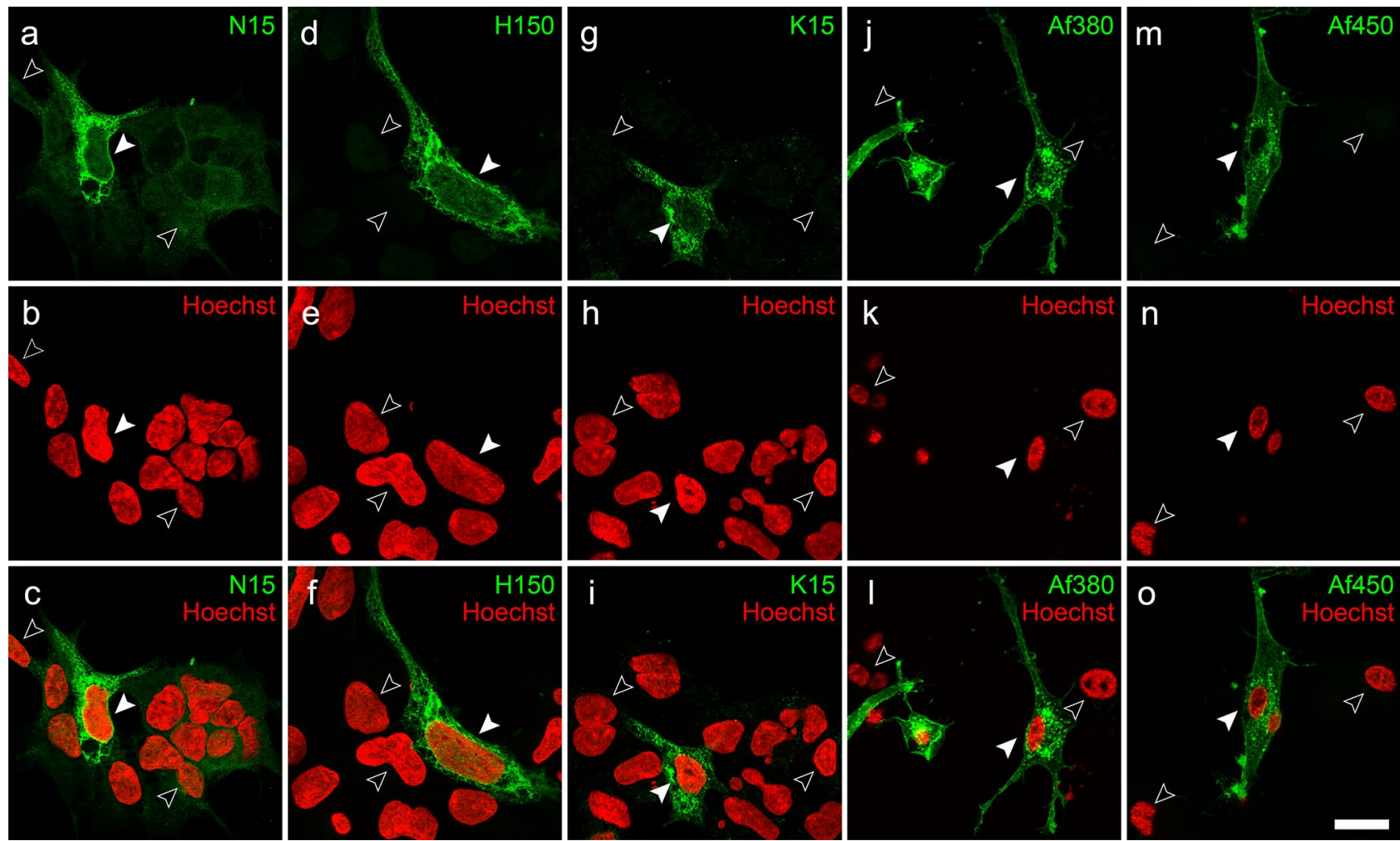

Fig. 2 Immunofluorescence labelling of $\mathrm{CB}_{1}$-transfected HEK293 cells (pseudocoloured green) with anti- $\mathrm{CB}_{1}$ polyclonal antibodies N15 (a-c), H150 (d-f), K15 (g-i), Af380 (j-l) and Af450 (m-o), combined with Hoechst's chromatin staining (pseudocoloured red). Filled and empty arrowheads correspond to transfected and non-

significant differences compared with the Af450/Af380 pair. As expected, the lowest coefficients were observed for the Af380/N15 combination, with a remarkably low mean value of $M 2(M 1,0.81 \pm 0.06 \mathrm{SD} ; M 2,0.50 \pm 0.21 \mathrm{SD})($ Fig. $3 \mathrm{~m})$, consistent with the observation that immunostaining with the Af380 antibody involved a considerably larger cell area than with $\mathrm{N} 15$, which was predominantly intracellular (Fig. 3a-c). In consequence, the resulting $M 1$ and $M 2$ coefficients were statistically lower compared with those obtained for the Af450/Af380 pair, whereas the value of $M 2$ was statistically different also for the comparison between the Af380-N15 and Af450-H150 combinations. In addition to yielding the highest Mander's overlap coefficients when combined, the Af380, Af450 and H150 antibodies produced the most intense immunofluorescence staining. Thus, Af380 showed the shortest exposure time to achieve immunofluorescence signal just below saturation, closely followed by Af450 and H150 antibodies (2.4 $\pm 1.2 \mathrm{SD}$ and $3.5 \pm 1.2 \mathrm{SD}$ fold longer exposure times, respectively). By contrast, much longer exposure times were observed with N15 and K15 antibodies $(13.3 \pm 4.7 \mathrm{SD}$ and $21.4 \pm 6.9 \mathrm{SD}$ fold longer, respectively). Measurement of Pearson's $R_{P}$ coefficients revealed a high degree of positive pixel intensity spatial transfected cells, respectively. Micrographs are maximum intensity projections of three consecutive optical sections separated by $0.24 \mu \mathrm{m}$, obtained by structured illumination microscopy. Scale bar: $20 \mu \mathrm{m}$ (applies to $\mathbf{a}-\mathbf{o}$ )

correlation between immunofluorescence signals generated by all couples of antibodies. Coste's randomization analysis yielded $R_{R}$ values close to 0 with a confidence limit above 99\% for all individual images, showing that Pearson's $R_{P}$ coefficients did not originate by random chance (Fig. 3n). Despite the significant positive correlation found in all antibody combinations, there were marked and statistically significant differences in $R_{P}$ values (Kruskal-Wallis ANOVA, $P<0.0001)$. Thus, the highest and lowest mean $R_{P}$ values for the co-localization within the dual colour fluorescence images corresponded to the Af450/Af380 and Af380/N15 combinations $(0.97 \pm 0.01 \mathrm{SD}$ and $0.77 \pm 0.10 \mathrm{SD}$, respectively), whereas Af450/H150 and Af380/K15 combinations yielded very high $R_{P}$ values $(0.88 \pm 0.05 \mathrm{SD}$ and $0.88 \pm 0.04$ $\mathrm{SD}$, respectively), but significantly lower in comparison with Af450/Af380 combination as revealed by Dunn's multiple comparison test $(P<0.01)$. Again, consistent with qualitative findings, the highest significance was detected between Af450/Af380 and Af380/N15 combinations $(P<0.001)$ (Fig. 3n).

To test the ability of anti- $\mathrm{CB}_{1}$ receptor $\mathrm{N}$-terminal antibodies to bind their target antigens in native conditions, double immunofluorescence assays were performed 
by incubation of live cells with either goat N15 or rabbit H150 polyclonal antibodies followed by paraformaldehyde fixation and incubation with rabbit Af380 and goat Af450 antibodies, respectively. In these conditions, plasma membrane staining with N15 antibody was variable among the $\mathrm{CB}_{1}$-transfected cell. Thus, N15 antibody detected clear plasma membrane staining after long exposure times in a subset of cells, causing a marked intracellular background autofluorescence to emerge (Fig. S1a-f). On the contrary, faint or no membrane staining was observed using similar acquisition settings in other cells (Fig. $4 \mathrm{a}-\mathrm{c}$ ). By contrast, H150 antibody systematically produced strong plasma membrane immunofluorescence staining, with virtually no background, which was highly co-localized with plasma membrane staining produced by Af450 antibody (Fig. 4d-f). These results indicate that antigen masking caused by paraformaldehyde fixation does not account for the different ability of N15 and H150 antibodies to detect $\mathrm{CB}_{1}$ receptors localized at the plasma membrane.

Next, the anti- $\mathrm{CB}_{1}$ antibodies were assayed by immunohistochemistry for their ability to specifically bind $\mathrm{CB}_{1}$ receptor on histological sections from paraformaldehyde-fixed adult rat brain cortex. Under these conditions, all the five antibodies led to an unevenly distributed immunostaining pattern throughout cortical layers I-VI. However, the dorsoventral distribution of immunolabelling and the types of detected cellular and subcellular structures varied considerably with the different antibodies used (Fig. 5a-j). Goat polyclonal antibodies N15 and $\mathrm{K} 15$, raised against the $\mathrm{N}$-terminal region and against a sequence within the cytosolic $\mathrm{C}$-terminal tail of $\mathrm{CB}_{1}$ receptor, respectively (Fig. 1), yielded a marked somatic immunostaining throughout cortical layers II-VI that was considerably more intense in layer $\mathrm{V}$ than in the rest (Fig. 5a, c). Immunolabelling with these two antibodies clearly delineated neuronal perikarya of variable morphology (Fig. 5f, h). A similar but more diffuse distribution pattern could be observed with the rabbit polyclonal antibody H150 (Fig. 5b, g), which was designed against a large peptide encompassing the extracellular N-terminal tail, the first transmembrane domain and most of the intracellular loop 1 of $\mathrm{CB}_{1}$ receptor (Fig. 1). By contrast, the anti-CB $\mathrm{CB}_{1}$ rabbit polyclonal Af380 and goat polyclonal Af450 antibodies, raised in rabbit against the $\mathrm{C}$-terminal 31 amino acids of $\mathrm{CB}_{1}$ receptor, produced a neuropil staining throughout the cortical depth, being more intense in layers II/III than in the rest (Fig. 5d, e). As seen at high magnification, this neuropil staining consisted of fibre profiles decorated with intensely stained presynaptic-like boutons (Fig. 5i, j). In summary, only Af380 and Af450 produced an immunostaining pattern consistent with the laminar and subcellular distribution previously described in the rodent brain cortex (Egertová and Elphick 2000; Bodor et al. 2005; Deshmukh et al. 2007).

To test the ability of the different antibodies to recognize denatured $\mathrm{CB}_{1}$ receptor from brain tissue, Western blot assays were performed in samples of P1, P2 and Cyt fractions obtained from adult rat brain cortex. Both N15 and K15 antibodies detected several bands migrating slightly below the $70 \mathrm{kDa}$ standard in $\mathrm{P} 1$ and $\mathrm{P} 2$ fractions, which were more intense in $\mathrm{P} 2$ than in $\mathrm{P} 1$ fraction (Fig. 5k, m). Additionally, N15 antibody detected a band migrating between the 75 and $100 \mathrm{kDa}$ standards in Cyt fraction (Fig. 5K) and K15 antibody yielded a net band of similar intensity $\mathrm{P} 1$ and $\mathrm{P} 2$ fractions and migrating above the $100 \mathrm{kDa}$ standard (Fig. $5 \mathrm{~m}$ ). In the three fractions analysed, intense bands were detected above the $50 \mathrm{kDa}$ standard with H150 antibody, with no clear differences in the signal intensity seen among the different fractions (Fig. 51). Both Af380 and Af450 antibodies detected a major band around the $50 \mathrm{kDa}$ standard in $\mathrm{P} 1$ and $\mathrm{P} 2$ but not in Cyt fraction (Fig. 5n-o). As a test of the specificity of immunohistochemical and Western blot staining, we performed immnohistochemical and Western blot assays before and after preadsorption of antibodies with the corresponding antigenic peptides, which were available for N15, K15, Af380 and Af450 antibodies, but not H150. Antigenpreabsorbed and non-preabsorbed N15 and K15 antibodies produced a similar pattern of immunohistochemical staining and detected similar bands in Western blot analysis (Fig. S2a, b), indicating that the signals observed resulted from non-specific binding of antibodies. By contrast, both immunohistochemical signals and the major immunoreactive band found in P1 and P2 fractions at $\sim 50 \mathrm{kDa}$ with both Af380 and Af450 antibodies were virtually undetectable following preadsorption of the primary antibodies with the specific blocking peptide (Fig. S2a, b). These findings suggested that both the immunohistochemical staining pattern observed and the $\sim 50 \mathrm{kDa}$ immunoreactive band detected in $\mathrm{P} 1$ fraction and P2 membranes resulted from specific binding of Af380 and Af450 antibodies to $\mathrm{CB}_{1}$ receptor.

The presence of an antigen preadsorption-sensitive $\sim 50 \mathrm{kDa}$ strong immunoreactivity band for anti-CB Af380 and Af450 antibodies in P1 samples (likely enriched in cell nuclei) prompted us to analyse the density of $\mathrm{CB}_{1}$ receptor-specific ligand binding sites in $\mathrm{P} 1$ fraction and to compare it with that in $\mathrm{P} 2$ membranes (known to be enriched in plasma membrane). To this end, we performed saturation binding experiments with the selective $\mathrm{CB}_{1}$ receptor radioligand antagonist $\left[{ }^{3} \mathrm{H}\right] \mathrm{SR} 141716 \mathrm{~A}(0.1-10 \mathrm{nM})$, showing that this compound labelled a single and homogeneous population of binding sites with a similar maximal density in both P1 and P2 samples (Fig. 6a), further demonstrating the presence of $\mathrm{CB}_{1}$ receptors in both fractions. Moreover, the $\mathrm{CB}_{1}$ receptor agonist WIN 55,212-2 was able to stimulate guanosine-5'-O- $\left(3^{-}\left[{ }^{35} \mathrm{~S}\right]\right.$ thio $)$-triphosphate $\left(\left[{ }^{35} \mathrm{~S}\right]\right.$ 

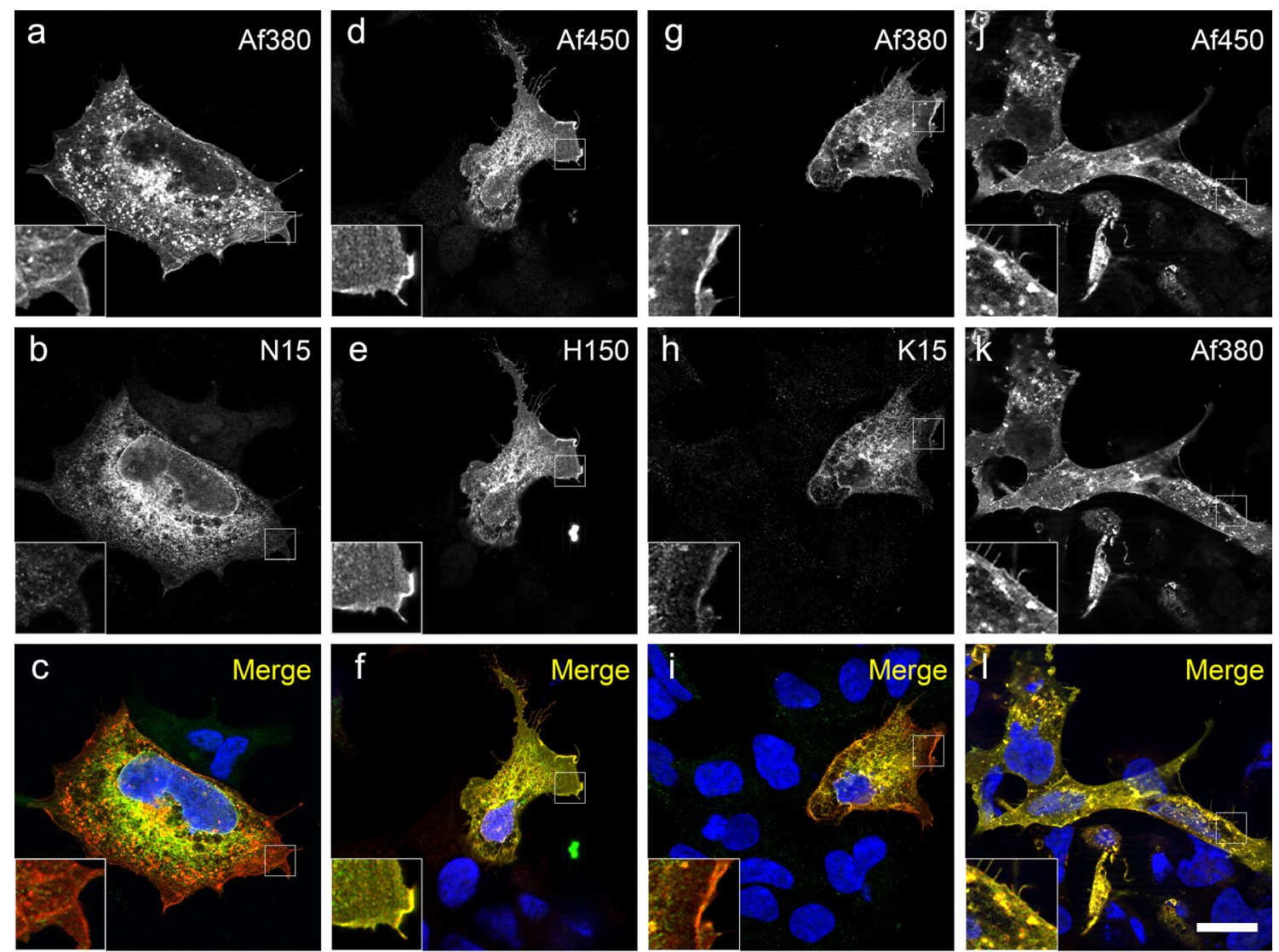

M Mander's Coefficients

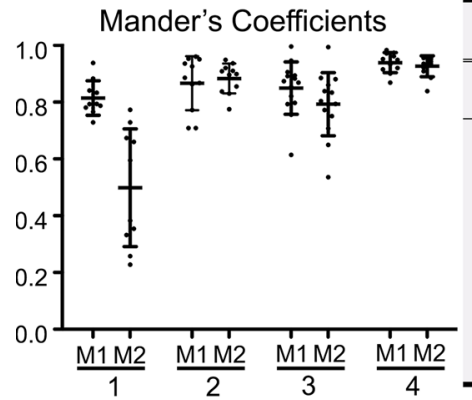

\begin{tabular}{|c|c|c|c|c|c|}
\hline \multicolumn{3}{|c|}{ Channels } & & \multicolumn{2}{|c|}{ Mander's coefficients } \\
\hline & Red & Green & $\mathbf{n}$ & M1 & M2 \\
\hline 1 & Af380 & N15 & 10 & $\Gamma 0.81 \pm 0.06$ & {$[*]^{0.50 \pm 0.21}$} \\
\hline 2 & Af450 & H150 & 11 & $0.87 \pm 0.10$ & ${ }^{*} 0.89 \pm 0.05$ \\
\hline 3 & Af380 & K15 & 14 & $0.85 \pm 0.09$ & ${ }_{*} 0.79 \pm 0.11$ \\
\hline 4 & Af450 & Af380 & 11 & {[]$_{0.94} \pm 0.04$} & {[]$_{0.93} \pm 0.04$} \\
\hline
\end{tabular}

$\mathrm{n}$

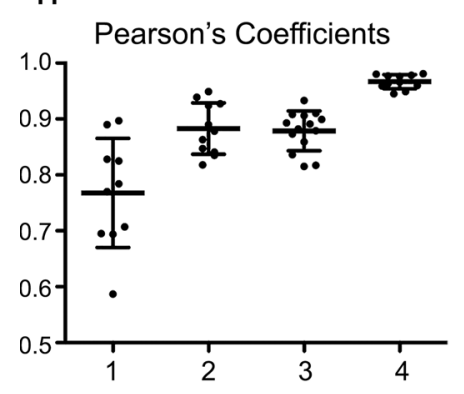

\begin{tabular}{cccc}
\hline \multicolumn{3}{c}{ Channels } \\
\hline \hline \multicolumn{2}{c}{ Red } & Green & n \\
\hline 1 & Af380 & N15 & 10 \\
2 & Af450 & H150 & 11 \\
3 & Af380 & K15 & 14 \\
4 & Af450 & Af380 & 11 \\
\hline
\end{tabular}

\begin{tabular}{|c|c|}
\hline \multicolumn{2}{|c|}{ Pearson's coefficients } \\
\hline $\mathbf{R}_{\boldsymbol{P}}$ & $\mathbf{R}_{R}$ \\
\hline$-0.77 \pm 0.10$ & $0.06 \pm 0.02$ \\
\hline ᄃ $0.88 \pm 0.05$ & $0.07 \pm 0.01$ \\
\hline $0.88 \pm 0.04$ & $0.04 \pm 0.01$ \\
\hline $0.97 \pm 0.01$ & $0.04 \pm 0.01$ \\
\hline
\end{tabular}

GTP $\gamma \mathrm{S}$ ) binding in both fractions, with a slightly higher efficiency and lower potency in P1 $(E \max =121.1 \pm 015.1 \%$ above basal; $\mathrm{EC}_{50}=0.63 \pm 0.06 \mu \mathrm{M}$ ) than in $\mathrm{P} 2$ $\left(E \max =89.5 \pm 7.3 \%\right.$ above basal; $\left.\mathrm{EC}_{50}=1.60 \pm 0.3 \mu \mathrm{M}\right)$ (Fig. 6a), showing that $\mathrm{CB}_{1}$ cannabinoid receptors are efficiently coupled to $G_{\mathrm{i} / \mathrm{o}}$ proteins in both $\mathrm{P} 1$ and $\mathrm{P} 2$ fractions from the adult rat cerebral cortex. Accordingly, key molecular components of this signal transduction pathway, i.e., $G$ inhibitory protein alpha subunits $\left(G \alpha_{i-1}, G \alpha_{i-2}\right.$ and $G \alpha_{i-3}$ ), could be detected by immunoblot in both fractions 
4Fig. 3 Double immunofluorescence labelling of $\mathrm{CB}_{1}$-transfected HEK293 cells $(\mathbf{a}-\mathbf{l})$ with combined goat and rabbit anti-CB ${ }_{1}$ receptor antibody couples: Af380/N15 (a-c), Af450/ H150 (d-f), Af380/K15 $(\mathbf{g}-\mathbf{i})$ and Af450/Af380 (j-l). Single-channel images shown in a, d, $\mathbf{g}, \mathbf{j}$ and in $\mathbf{b}, \mathbf{e}, \mathbf{h}, \mathbf{i}$ were pseudocoloured red and green, respectively, and together with Hoechst's chromatin staining to generate images shown in $\mathbf{c}, \mathbf{f}, \mathbf{i}, \mathbf{l}$. Scale bar: $20 \mu \mathrm{m}$ (applies to $\mathbf{a}-\mathbf{l}$ ). Micrographs are maximum intensity projections of three consecutive optical sections separated by $0.24 \mu \mathrm{m}$, obtained by structured illumination microscopy $(\mathbf{m}-\mathbf{n})$. Measurement of the Mander's pixel overlap $M 1$ and $M 2$ and Pearson's $R_{P}$ pixel intensity correlation coefficients between the two immunofluorescence signals of doubly immunostained cells. Graphs in $\mathbf{m}-\mathbf{n}$ show plots and mean \pm SD values of the Mander's and Pearson's coefficients. Kruskal-Wallis ANOVA yielded statistically significant differences between groups for $M 1(P<0.005)$ and $M 2$ coefficients $(P<0.0001)$ and $R_{P}(P<0.0001)$ values. Asterisks in tables refer to significant differences from Dunn's multiple comparison test $(* P<0.05 ; * * P<0.01 ; * * * P<0.001)$

by using an antibody raised against a peptide common to three major $\mathrm{G}$ inhibitory protein alpha subunits $\left(G \alpha_{i-1}, G \alpha_{i-2}\right.$ and $G \alpha_{i-3}$ ) (Fig. 6b). To ascertain whether the concurrence of $\mathrm{CB}_{1}$-immunoreactivity, $\mathrm{CB}_{1}$ receptor-specific ligand binding and $\mathrm{CB}_{1}$ receptor agonist-stimulated $\left[{ }^{35} \mathrm{~S}\right] \mathrm{GTP} \gamma \mathrm{S}$ binding in $\mathrm{P} 1$ nuclear fractions could be explained by the presence of cell membranes pelleted during the first centrifugation step after tissue homogenization, we performed Western blot experiments in P1, P2 and Cyt fractions using specific markers of subcellular compartments (see Table S1 for details). Although P1 membranes displayed immunoreactivity for NPCx and histone $\mathrm{H} 1$ proteins, revealing the enrichment of P1 in cell nuclei, strong immunoreactivity was also observed for the plasma membrane markers $\mathrm{Na}^{+}$/ $\mathrm{K}^{+}$ATPase, NMDAR1 and SNAP25, whereas no signal was detected for the cytosolic marker $\beta$-tubulin (Fig. 6c). Therefore, the concurrence of $\mathrm{CB}_{1}$ immunoreactivity, $\mathrm{CB}_{1}$ receptor-specific ligand binding sites and $\mathrm{CB}_{1}$ receptor coupling to $G_{\mathrm{i} / \mathrm{o}}$ proteins in $\mathrm{P} 1$ fractions was very likely due to the presence of cell membranes in these samples.

The results shown so far demonstrate that all the five antibodies tested are able to bind $\mathrm{CB}_{1}$ receptors in transiently transfected HEK-293 cells, although with variable capacity to detect discrete subcellular pools of $\mathrm{CB}_{1}$ receptor (Figs. 2-4, S1). However, only Af380 and Af450 antibodies clearly labelled axons and presynaptic-like boutons in tissue sections of the adult rat cortex, consistent with the expected distribution of $\mathrm{CB}_{1}$ receptor (Figs. 5, S2). Therefore, we attempted to rescue (N15, H150 and K15 antibodies) and/ or enhance (Af380 and Af450) specific immunostaining with all the five antibodies in sections of adult rat brain cortex, using a fixation method, consisting of a brief perfusion with sodium sulphide buffer before aldehyde fixation, which has been previously shown to improve antibody sensitivity without compromising specificity for a variety of antigens (Mitchell et al. 1993; Montaña et al. 2012; García del Caño et al. 2015). Under these conditions, N15, H150 and K15 antibodies produced a similar pattern as compared with standard conditions, and immunostaining was insensitive to preadsorption of N15 and K15 antibodies with their corresponding blocking peptides. By contrast, under sulphide fixation, Af380 immunostaining intensity increased considerably in axonal profiles and presynaptic-like puncta throughout the depth of the cortex, particularly in layers II/III (Fig. S3 and Supplementary results for further details). Strikingly, in cortical tissue subjected to sodium sulphide fixation, Af450 antibody produced a somatic immunostaining composed of round profiles that resembled cell nuclei, along with the axonal and presynaptic-like immunostaining pattern already observed under standard fixation (Fig. S4 and Supplementary results for further details). Combination of Af450 and anti-lamin B1 antibodies in double immunofluorescence assays revealed the presence of Af450 immunoreactivity in large and medium sized nuclei of the rat cortex (Fig. 7b, c), and this particular labelling pattern was mostly internal to the nuclear lamina (Fig. 7a-c, Insets). Of note, preadsorption of the primary antibody with the specific blocking peptide abolished both presynaptic and nuclear staining produced by Af450 antibody (Fig. 7d-f), showing that sulphide fixation unmasks binding sites of Af450 antibody within the nucleus without affecting the presynaptic staining observed in sections from brain tissue fixed by the standard method.

To analyse more in depth the origin of the nuclear signal observed with Af450 antibody, we isolated highly purified intact nuclei ( $\mathrm{N}$ fraction) from the adult rat cortex (Fig. 8a) for Western blot and immunofluorescence analysis. Immunoblot on $\mathrm{N}$ samples using the Af450 antibody yielded a net band at $\sim 60 \mathrm{kDa}$ clearly above the theoretical $52 \mathrm{kDa}$ molecular mass of rat $\mathrm{CB}_{1}$ receptor observed in $\mathrm{P} 2$ samples (Fig. 8b). Consistent with that observed in tissue sections under sulphide fixation, Af450 antibody produced strong immunoreactivity in intact nuclei isolated from the adult rat cortex. Notably, co-immunolabelling with the neuronal marker NeuN/Fox-3 revealed that only neuronal nuclei were Af450 positive (Fig. 8c-e). Again, Af450 immunoreactivity in $\mathrm{N}$ samples was virtually abolished by preadsorption of the primary antibody with the immunizing peptide, both in Western blot (Fig. 8b) and immunofluorescence assays (Fig. 8f-g). High-resolution images showed that Af450 immunoreactivity was distributed throughout the nucleoplasm in subdomains poor in chromatin (Fig. 8h, S5a-c), internal to the nuclear lamina (Fig. S5d-f) and partially overlapping with components of the nuclear matrix NeuN/ Fox-3 (Fig. S5g-i) and SC35 (Fig. S5j-1), which is inconsistent with the expected localization of an integral membrane protein, which is predicted to partition into cell membranes. These results, pointing strongly to the conclusion that the signal detected by the Af380 antibody in nuclei is non-specific, were confirmed by saturation radioligand binding and agonist-stimulated $\left[{ }^{35} \mathrm{~S}\right] \mathrm{GTP} \gamma \mathrm{S}$ binding assays in $\mathrm{N}$ samples, 

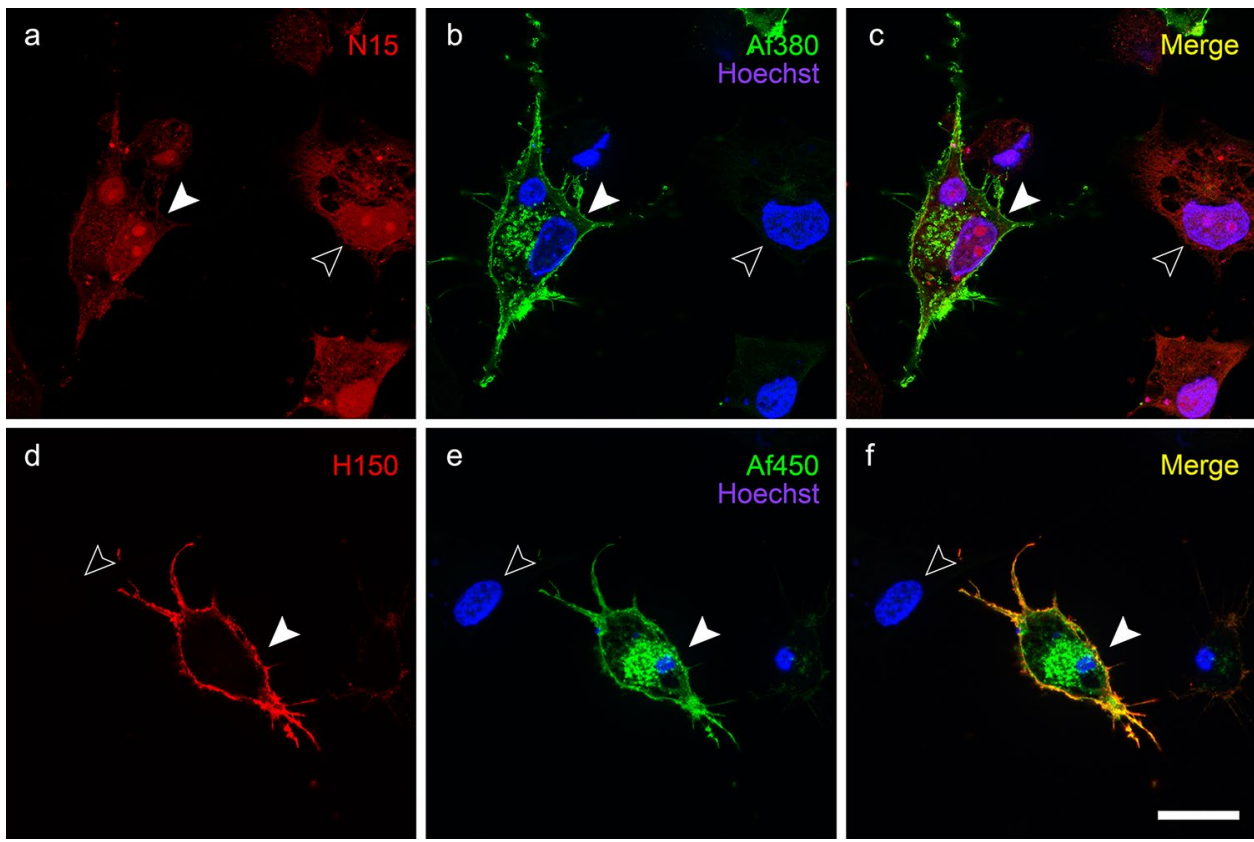

Fig. 4 Live immunolabelling of in $\mathrm{CB}_{1}$-transfected HEK293 cells with $\mathrm{N} 15$ and $\mathrm{H} 150$ antibodies (pseudocoloured red), raised against the extracellular amino-terminal tail of $\mathrm{CB}_{1}$ receptor, followed by cell fixation-permeabilization and co-immunolabelling with Af380 (a-c) and Af450 (d-f) antibodies (pseudocoloured green), raised against the carboxy-terminus of $\mathrm{CB}_{1}$ receptor. Nuclei were counterstained

since no $\mathrm{CB}_{1}$ receptor-specific sites or agonist-stimulated $\mathrm{CB}_{1}$ receptor coupling could be detected (see Fig. S6 for details).

Regardless of the non-specific binding or Af450 antibody to a nuclear protein, only Af380 and Af450 antibodies passed the specificity tests in all samples and conditions used so far. Therefore, to further analyse $\mathrm{CB}_{1}$ receptor-specific and non-specific signals produced by these two antibodies, we performed immunohistochemical and Western blot analyses in $\mathrm{CB}_{1}-\mathrm{WT}$ and $\mathrm{CB}_{1}-\mathrm{KO}$ mice of the Ledent's line (Ledent et al. 1999). Since, in sections of the rat cerebral cortex, the Af380 antibody produced a stronger immunohistochemical signal under sulphide fixation (compared with the standard method) and sulphide fixation unmasked non-specific binding sites of the Af450 antibody, we used tissue processed under these conditions for immunohistochemistry in $\mathrm{CB}_{1}-\mathrm{WT}$ and $\mathrm{CB}_{1}-\mathrm{KO}$ mice. The immunohistochemical patterns produced by Af380 and Af450 antibodies in sulphidefixed cerebral cortex sections of $\mathrm{CB}_{1}-\mathrm{WT}$ adult mice were qualitatively indistinguishable from those observed in the adult rat cortex; i.e., Af380 antibody produced a neuropil staining consisting of a network of axonal profiles with a characteristic layered-pattern distribution (Fig. 9a, c, e), whereas Af450 antibody produced the same pattern, along with a strong immunostaining in cell nuclei (Fig. 9g, i, using Hoechst nuclear stain. Single-channel images shown in $\mathbf{a}, \mathbf{b}$ and d, e were merged together with Hoechst's chromatin staining (shown in $\mathbf{c}$ and $\mathbf{f}$, respectively). Micrographs are maximum intensity projections of three consecutive optical sections separated by $0.24 \mu \mathrm{m}$, obtained by structured illumination microscopy. Scale bar: $20 \mu \mathrm{m}$ (applies to $\mathbf{a}-\mathbf{l}$ )

k) as we had observed in the adult rat cortex. In $\mathrm{CB}_{1}-\mathrm{KO}$ mice, immunostained sections of $\mathrm{CB}_{1}-\mathrm{KO}$ mice with either of the two antibodies were completely devoid of fibres and presynaptic-like puncta (Fig. 9b, d, f, h, j, l). However, the Af380 antibody produced a pale but clearly prominent immunostaining against the surrounding unlabelled neuropil in numerous cell bodies (Fig. 9b, d, f), whereas the Af450 antibody stained numerous cell nuclei (Fig. 9h, j, 1) consistent with a non-specific nature of nuclear staining. Non-specific signals produced by both antibodies were particularly prominent in layer V. Before carrying out Western blot analysis on isolated subcellular fractions from $\mathrm{CB}_{1}-\mathrm{WT}$ and $\mathrm{CB}_{1}-\mathrm{KO}$ mice, samples from both genotypes were analysed by $\mathrm{CB}_{1}$ receptor agonist-induced $\left[{ }^{35} \mathrm{~S}\right]$ GTP $\gamma \mathrm{S}$ binding and by PCR amplification, respectively. As expected, the $\mathrm{CB}_{1}$ receptor agonist WIN 55,212-2 was able to stimulate $\left[{ }^{35} \mathrm{~S}\right] \mathrm{GTP} \gamma \mathrm{S}$ binding in $\mathrm{P} 2$ samples from CB-WT but not $\mathrm{CB}_{1}$-KO mice (Fig. S7). Likewise, PCR amplification in cDNA samples obtained by reverse transcription of total RNA (Fig. S8) (isolated from a small piece of the cortical tissue used for Western blotting of intact nuclei) yielded specific PCR products with the three primer pairs used in $\mathrm{CB}_{1}-\mathrm{WT}$ but not $\mathrm{CB}_{1}-\mathrm{KO}$ mice (Fig. S9). Because the strategy to generate Ledent's $\mathrm{CB}_{1}-\mathrm{KO}$ mouse line led to a null allele that still contains the triplets of Cnr1 gene coding for amino acids 235-473 (Ledent 


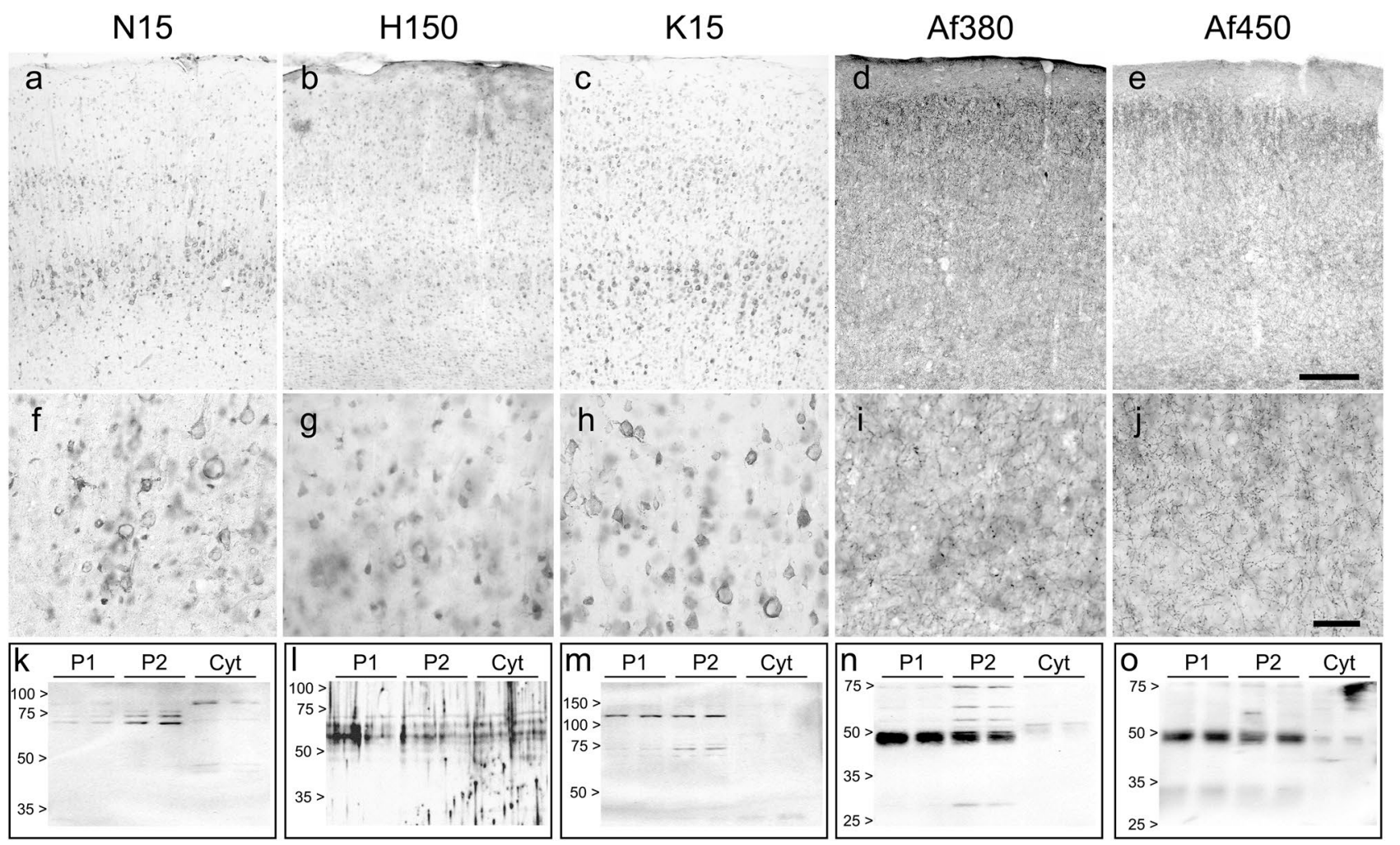

Fig. 5 (a-j) Micrographs of coronal sections of the adult rat parietal cortex immunostained with the different antibodies designed against $\mathrm{CB}_{1}$ receptor tested here. (a-e) Low-magnification micrographs show the overall distribution of immunoreactivity throughout the depth of the cortex using the different antibodies. $(\mathbf{f}-\mathbf{j})$ Higher-magnification micrographs show details of the immunostaining pattern in cortical

et al. 1999) (Fig. S9a), results of PCR amplification also ruled out the possibility that a transcript containing the coding sequence for the immunizing peptide (residues 443-473 of mouse $\mathrm{CB}_{1}$ receptor) could be still expressed in $\mathrm{CB}_{1}-\mathrm{KO}$ mice, thus hindering the interpretation of nonspecific signals observed with Af380 and Af450 (Fig. S9 and Supplementary results for further details). Western blot analysis of $\mathrm{P} 2$ membranes from $\mathrm{CB}_{1}-\mathrm{WT}$ and $\mathrm{CB}_{1}-\mathrm{KO}$ mice showed that Af380 antibody produced a major band at $\sim 50 \mathrm{kDa}$, which was absent in $\mathrm{P} 2$ samples from $\mathrm{CB}_{1}-\mathrm{KO}$ mice, and a second, less intense but clearly positive band around the $20 \mathrm{kDa}$ standard, which still remained in samples from $\mathrm{CB}_{1}-\mathrm{KO}$ mice. By contrast, a single weak band was observed in $\mathrm{N}$ samples, from both $\mathrm{CB}_{1}-\mathrm{WT}$ and $\mathrm{CB}_{1}$-KO mice, immunoblotted with Af380 antibody. As observed in $\mathrm{P} 2$ samples from the adult rat brain, the Af450 antibody produced a single specific band at $\sim 50 \mathrm{kDa}$ only in $\mathrm{P} 2$ fractions from $\mathrm{CB}_{1}-\mathrm{WT}$ but not $\mathrm{CB}_{1}-\mathrm{KO}$ animals, whereas it detected a single intense band at $\sim 60 \mathrm{kDa}$ in $\mathrm{N}$ samples obtained from either phenotype (Fig. 9o). Overall, these results show that Af380 and Af450 antibodies bind, both in tissue sections and in denatured samples resolved layer V. Scale bars: $200 \mu \mathrm{m}$ in $\mathbf{e}$ (applies to $\mathbf{a}-\mathbf{e}$ ); $50 \mu \mathrm{m}$ in $\mathbf{j}$ (applies to $\mathbf{f}-\mathbf{j})$. (k-o) Western blot analysis using the different antibodies against the $\mathrm{CB}_{1}$ receptor tested in this study. Equivalent amounts of protein $(20 \mu \mathrm{g} / \mathrm{lane})$ from P1, P2 and Cyt fractions obtained from homogenates of adult rat brain cortex were loaded in duplicate and run in parallel

by SDS-PAGE, not only to the $\mathrm{CB}_{1}$ receptor but also to non- $\mathrm{CB}_{1}$ receptor targets.

To confirm immunohistochemical results obtained in Ledent's $\mathrm{CB}_{1}$-WT and $\mathrm{CB}_{1}$-KO mice, Af380 and Af450 antibodies were assayed in brain sections of $\mathrm{CB}_{1}-\mathrm{WT}$ and $\mathrm{CB}_{1}-\mathrm{KO}$ animals kindly provided by Dr. Giovanni Marsicano (Marsicano et al. 2002), which were generated using a Cre/loxP-based gene-targeting strategy that involves removal of the entire Cnrl coding region. The immunohistochemical patterns produced by Af380 and Af450 in sulphidefixed cerebral cortical sections of $\mathrm{CB}-1 \mathrm{WT}$ and $\mathrm{CB}_{1}-\mathrm{KO}$ littermates from this line were virtually identical to those observed in Ledent's model (Fig. S10).

\section{Discussion}

It is well known that the ability of antibodies to recognize their target antigen is highly influenced by the experimental context in which they are used and, therefore, not all antibodies are suitable for all end-use applications (Bordeaux et al. 2010; Voskuil 2014, 2017; Uhlen et al. 2016). The analysis 

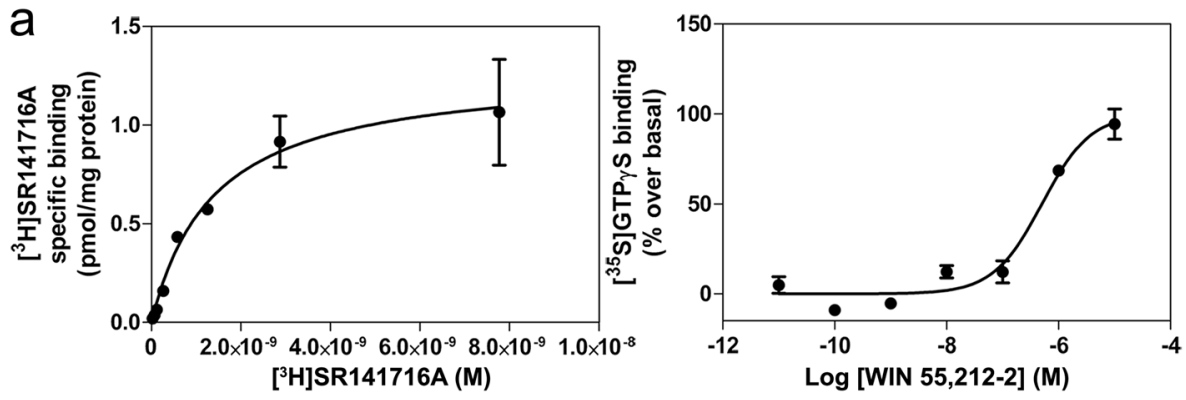

\begin{tabular}{ccccc} 
& \multicolumn{2}{c}{ P1 fraction } & \multicolumn{2}{c}{ P2 fraction } \\
\hline \multirow{2}{*}[{}^{3}\mathrm{H}]{ SR141716A binding } & $B_{\max }(\mathrm{pmol} / \mathrm{mg})$ & $K_{D}(\mathrm{nM})$ & $B_{\max }(\mathrm{pmol} / \mathrm{mg})$ & $K_{D}(\mathrm{nM})$ \\
& $0.99 \pm 0.2$ & $1.88 \pm 0.9$ & $1.04 \pm 0.2$ & $1.57 \pm 0.5$ \\
\hline
\end{tabular}

WIN55,212-2 stimulated $E_{\max }\left(\%\right.$ over basal) $E C_{50}(\mu \mathrm{M}) \quad E_{\max }\left(\%\right.$ over basal) $E C_{50}(\mu \mathrm{M})$ $\left[{ }^{35} \mathrm{~S}\right] \mathrm{GTPYS}$ binding
$1.60 \pm 0.3$
$89.5 \pm 7.3$

$0.63 \pm 0.1$

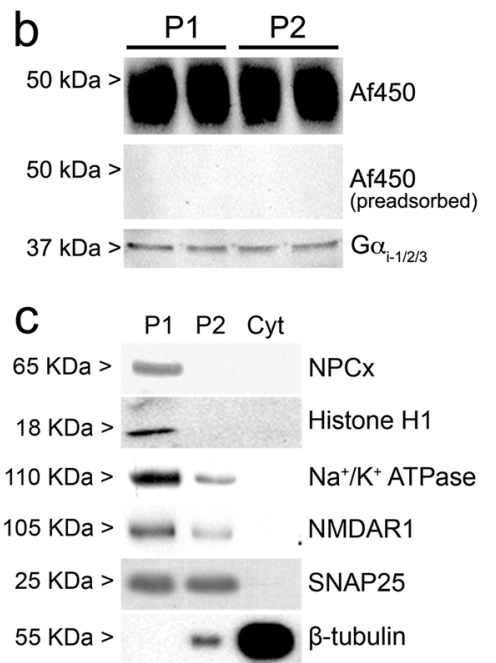

Fig. 6 a Radioligand and $\left[{ }^{35} \mathrm{~S}\right] \mathrm{GTP} \gamma \mathrm{S}$ binding assays in P1 and P2 fractions from the adult rat brain cortex. Representative saturation binding curve for $\left[{ }^{3} \mathrm{H}\right] \mathrm{SR} 141716 \mathrm{~A}(0.01-10 \mathrm{nM})$ and representative dose-response curve of WIN 55,212-2 $(0.1 \mathrm{nM}-10 \mu \mathrm{M})$ stimulated $\left[{ }^{35} \mathrm{~S}\right] \mathrm{GTP} \gamma \mathrm{S}$ binding (right), both in P1 fraction from the adult rat cortex. Non-specific binding in stimulated $\left[{ }^{35} \mathrm{~S}\right] \mathrm{GTP} \gamma \mathrm{S}$ binding assays was determined in the presence of $10 \mu \mathrm{M}$ unlabelled GTP $\gamma \mathrm{S}$. Each point in both curves corresponds to the mean \pm SEM value of one representative experiment performed in triplicate and duplicate for radioligand and $\left[{ }^{35} \mathrm{~S}\right] \mathrm{GTP} \gamma \mathrm{S}$ binding assays, respectively. The accompanying table shows maximal number of sites $\left(B_{\max }\right)$ and affinity $\left(K_{D}\right)$ values for the selective $\mathrm{CB}_{1}$ receptor antagonist $\left[{ }^{3} \mathrm{H}\right] \mathrm{SR} 141716 \mathrm{~A}$ and the maximal effect $\left(E_{\max }\right)$ and potency $\left(\mathrm{EC}_{50}\right)$ of the $\mathrm{CB}_{1}$ cannabi- noid receptor agonist WIN 55,212-2 to stimulate $\left[{ }^{35} \mathrm{~S}\right] \mathrm{GTP} \gamma \mathrm{S}$ binding assays in $\mathrm{P} 1$ and $\mathrm{P} 2$ subcellular fractions of the adult rat cortex. Values shown in the table are mean \pm SEM of at least three independent experiments. b Western blot analysis against $\mathrm{CB}_{1}$ receptor and $\mathrm{G}$ inhibitory protein alpha subunits $\left(G \alpha_{\mathrm{i}^{-}}{ }^{1,2,3}\right)$ in both P1 and P2 subcellular fractions from adult rat brain cortex $(20 \mu \mathrm{g} / \mathrm{lane})$. c Western blot analysis of P1, P2 and Cyt fractions from the adult rat cortex (10 $\mu \mathrm{g} /$ lane) with antibodies against subcellular fraction-specific antigens: NPCx (62 kDa component of the nuclear pore complex), Histone H1, $\mathrm{Na}^{+} / \mathrm{K}^{+}$ATPase $\left(\alpha_{1}\right.$ subunit of $\mathrm{Na}^{+} / \mathrm{K}^{+}$ATPase); NMDAR1 (NR1 subunit of the NMDA receptor), SNAP25 (synaptosome-associated protein 25) and $\beta$-tubulin (see Supplementary Table S1 for further details)
Fig. 7 a-c Double immunofluorescence labelling in the adult rat cortex under sodium sulphide fixation combining a mouse monoclonal antibody recognizing the nuclear protein lamin B1 (pseudocoloured red) and the goat polyclonal anti- $\mathrm{CB}_{1}$ antibody Af450 (pseudocoloured green). The anti- $\mathrm{CB}_{1}$ antibody immunostained presynaptic-like boutons (arrowheads) as well as large and medium sized (filled arrows) but not small nuclei (empty arrows), as seen by co-staining with lamin B1. d-f The same experiment depicted in $\mathbf{a}-\mathbf{c}$ was performed after preadsorption of the anti- $\mathrm{CB}_{1}$ with the immunizing peptide. Images are single 0.5 - $\mu \mathrm{m}$-thick confocal optical sections. Scale bar: $50 \mu \mathrm{m}$ in $\mathbf{f}$ (applies to $\mathbf{a}-\mathbf{f})$
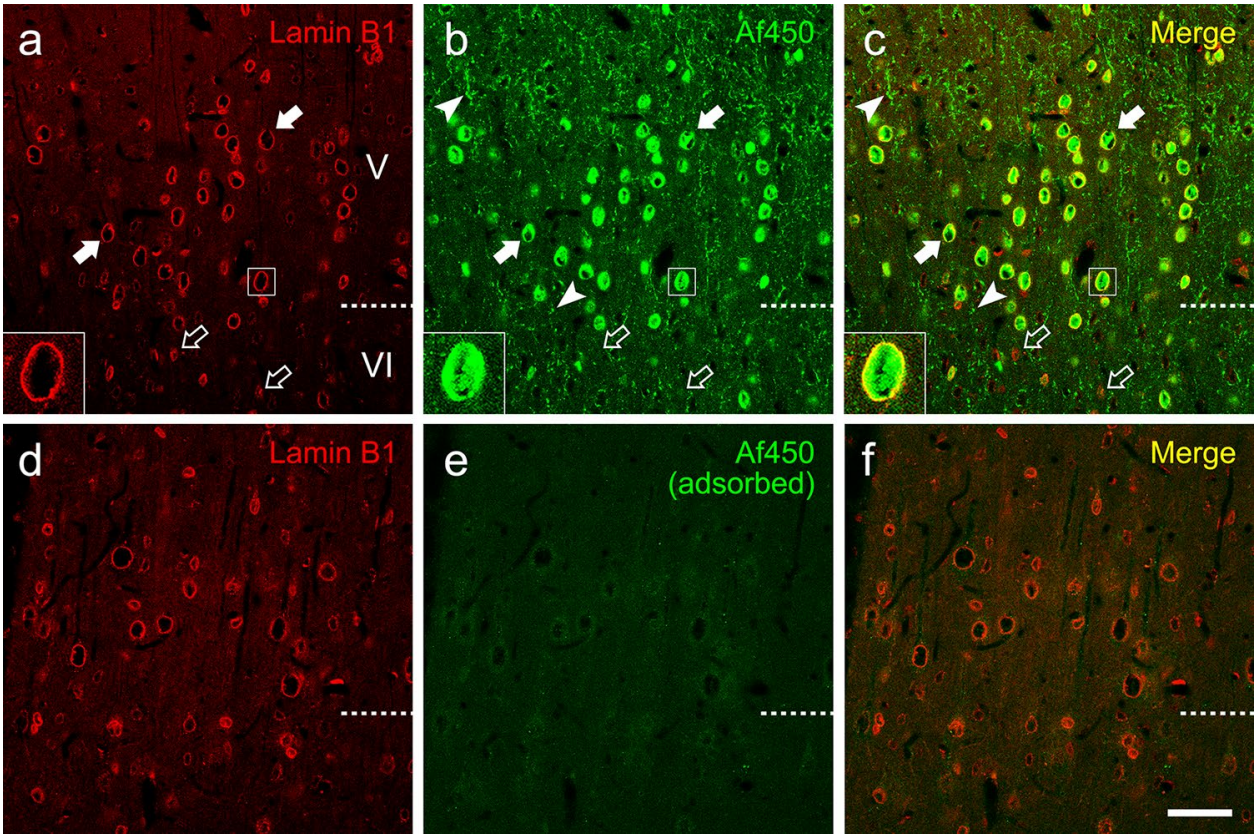

performed here focused on the ability of five anti-CB recep- $_{1}$ tor antibodies of commercial source, designed against the N-terminal (N15 and H150) or C-terminal (K15, Af380 and
Af450) regions of the $\mathrm{CB}_{1}$ receptor, to specifically recognize their target in cells transfected with plasmids coding for the native human $C_{1}$ receptor, in fixed sections from rat and 


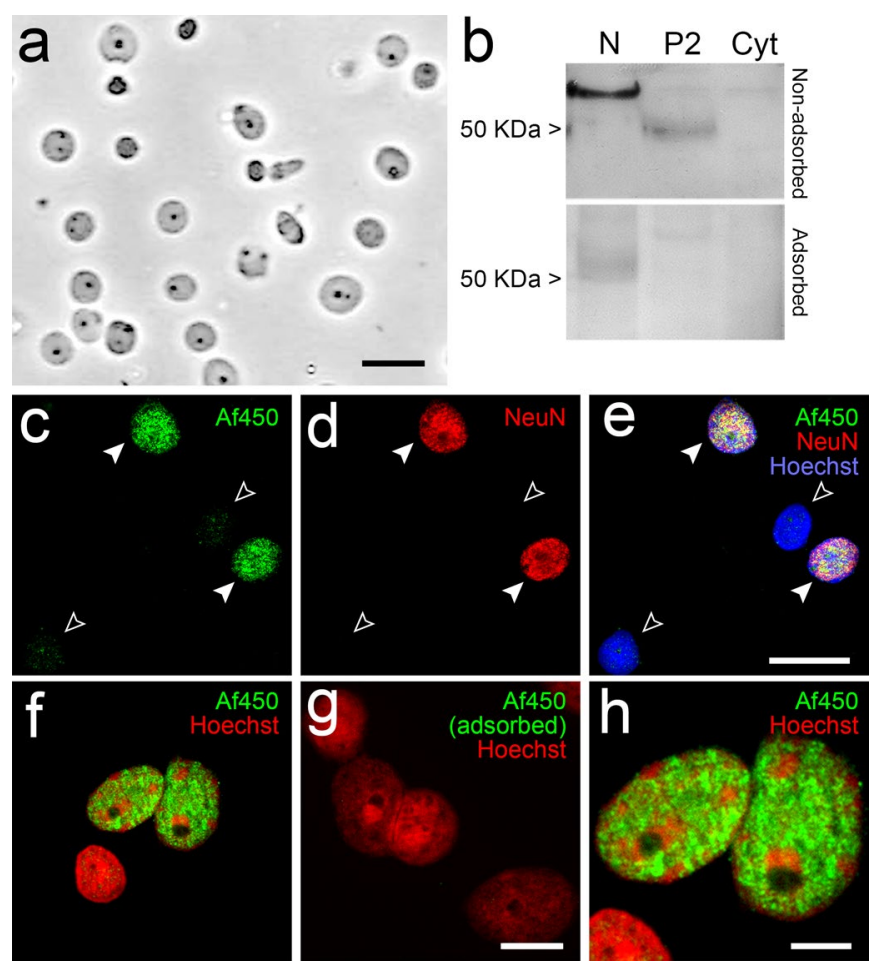

Fig. 8 Analysis of immunoreactivity of the goat polyclonal Af450 antibody in intact nuclei $(\mathrm{N})$ isolated from adult rat brain cortex. a Representative image of phase-contrast microscopy of nuclei isolated from a homogenate of adult rat cerebral cortex showing no debris or contamination by other organelles. Scale bar: $20 \mu \mathrm{m}$. b Western blot analysis of N, P2 and Cyt from the adult rat brain cortex using Af450 antibody. Bands of $\sim 62 \mathrm{kDa}$ and $\sim 50 \mathrm{kDa}$ detected in $\mathrm{N}$ and $\mathrm{P} 2$ samples, respectively, disappeared after preadsorption of the antibody with the immunizing peptide. Equal amounts of protein $(10 \mu \mathrm{g} / \mathrm{lane})$ were loaded and run in parallel. c-e Double immunofluorescence labelling with Af450 (pseudocoloured green) and anti-NeuN/Fox-3 (NeuN, pseudocoloured green) antibodies combined with Hoechst's

mouse cerebral cortex and in subcellular fractions obtained from rat and mouse brain cortex homogenates. In addition, $\mathrm{N} 15$ and $\mathrm{H} 150$ antibodies were tested for their ability to detect surface $\mathrm{CB}_{1}$ receptor in live cells.

In HEK-293 cells fixed with paraformaldehyde, all the five antibodies tested made it possible to readily distinguish cells transfected with the $\mathrm{CB}_{1}$ receptor from non-transfected ones. However, whereas the $\mathrm{N}$-terminal $\mathrm{H} 150$ antibody and the C-terminal Af 380 and Af450 antibodies produced bright signals that were highly co-localized with each other both intracellularly and on the plasma membrane, the N-terminal N15 and C-terminal K15 antibodies barely and weakly detected surface receptors, respectively. Noteworthy, the H150 antibody was also highly specific and sensitive in detecting surface $\mathrm{CB}_{1}$ receptors in live cells, which contrasts with the uselessness of the N15 antibody for this purpose. The distinct peptides used as antigen to generate N15 and H150 antibodies could explain this difference. Indeed, staining (pseudocoloured blue). The Af450 antibody detected a strong signal in every $\mathrm{NeuN}$-immunopositive nucleus (filled arrowheads), whereas very weak or no staining was observed in nuclei devoid of NeuN/Fox-3 (empty arrowheads). Scale bar: $20 \mu \mathrm{m}$ in e (applies to c-d). f-h Combined immunofluorescence with the Af450 antibody (pseudocoloured green) and Hoechst's chromatin staining (pseudocoloured red) in isolated cell nuclei from the adult rat cortex before (f) and after (g) incubation of the primary antibody with the specific blocking peptide. The higher-magnification micrograph (h) of the nuclei shown in $\mathbf{f}$ depicts the non-overlapping pattern between Af380 immunofluorescence and patches of intense Hoechst's staining. Scale bars: $10 \mu \mathrm{m}$ in $\mathbf{g}$ (applies to $\mathbf{f}-\mathbf{g}$ ); $5 \mu \mathrm{m}$ in $\mathbf{h}$

the N15 antibody was raised against an unspecified short sequence near the end of the $\mathrm{N}$-terminal extracellular tail of the human $\mathrm{CB}_{1}$ receptor, whereas the $\mathrm{H} 150$ antibody was raised against a long peptide spanning residues $1-150$ of the human $\mathrm{CB}_{1}$ receptor and, therefore, likely to contain more immunogenic sequences. However, this would only explain the differences in sensitivity but not the different ability to detect the surface receptor. Interestingly, it has been demonstrated that a large fraction of $\mathrm{CB}_{1}$ receptor are truncated at their $\mathrm{N}$-terminal at early stages in the secretory pathway just before being translocated to the endoplasmic reticulum (ER) (Nordström and Andersson 2006), whereas the untruncated receptors appear to be inefficiently translocated across the ER membrane, leading to high levels of misfolded receptor that are subsequently degraded (Andersson et al. 2003). Although the extent of this truncation has not yet been determined, endogenous truncation of $\mathrm{N}$-terminally c-myc-tagged $\mathrm{CB}_{1}$ receptors overexpressed in baby hamster kidney cells 

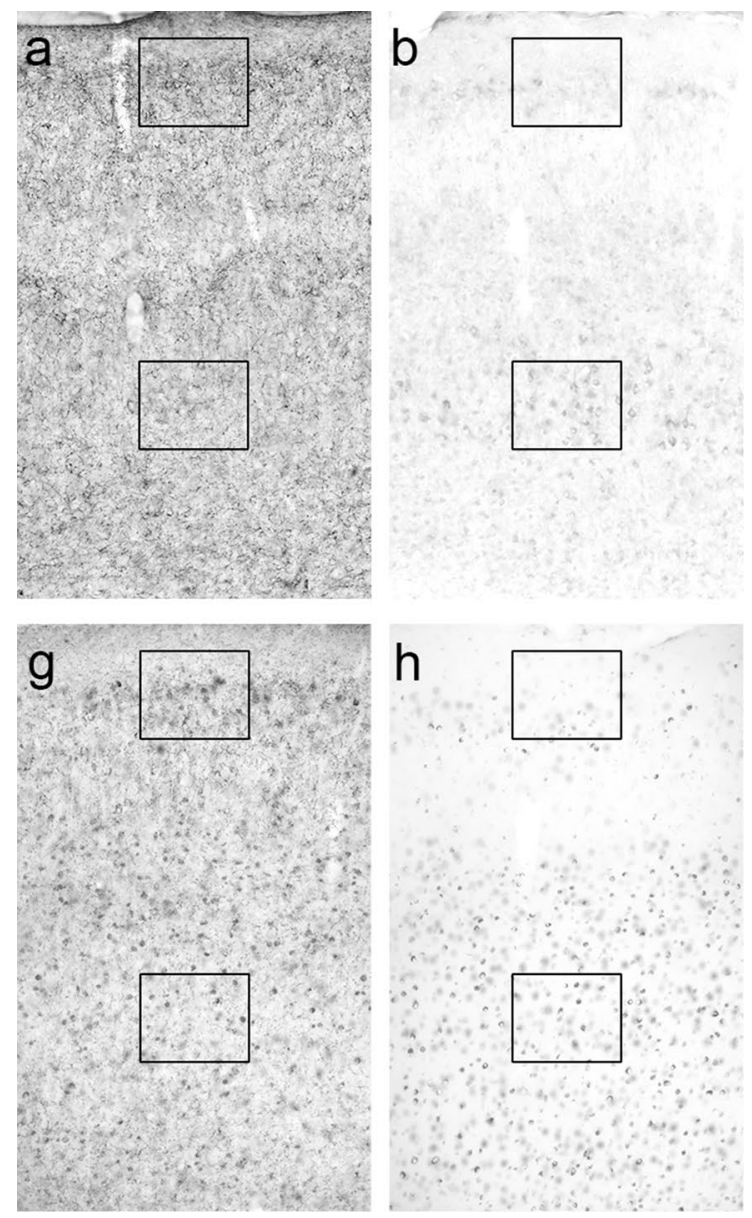

$\mathrm{m}$

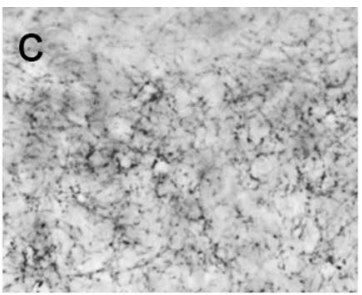

d
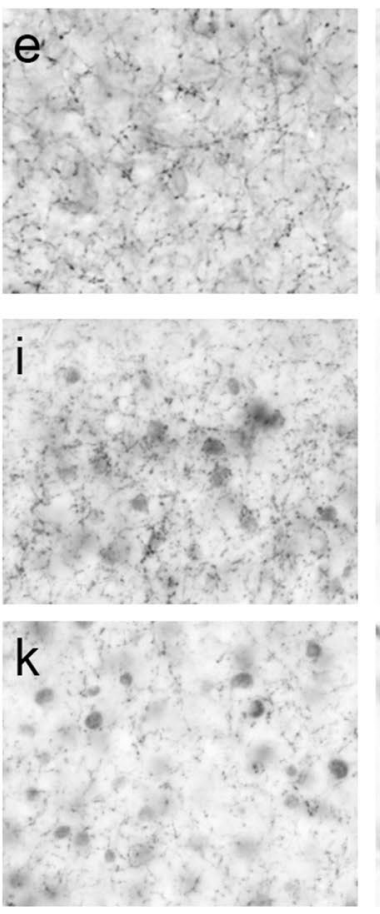

WT

$\mathrm{KO}$ $\frac{(20 \mu g)}{\mathrm{P} 2 \mathrm{~N}} \frac{(40 \mu \mathrm{g})}{\mathrm{P} 2 \mathrm{~N}}$

o

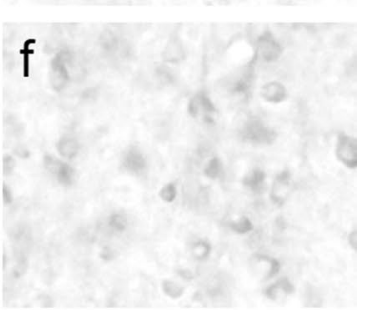

j

WT $\quad \mathrm{KO}$

WT KO
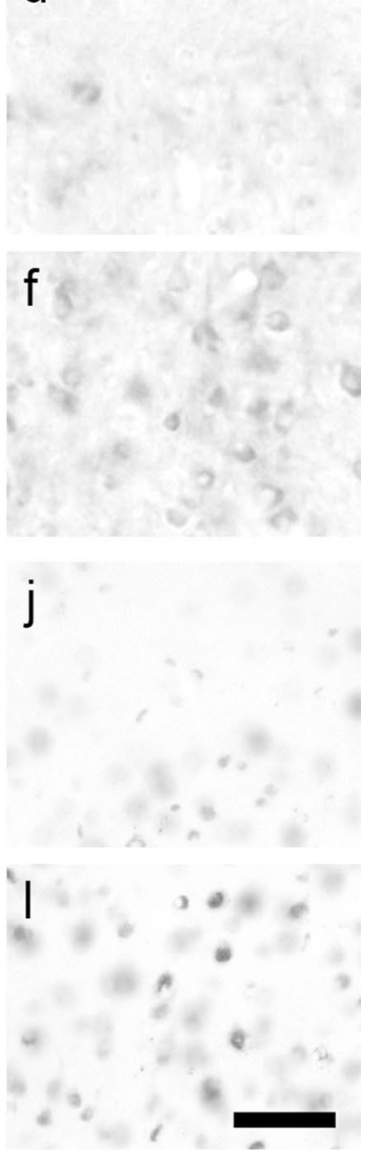

\section{$\overline{\mathrm{P} 2 \mathrm{~N}} \frac{(4 \mathrm{P} 2 \mathrm{~N}}{\mathrm{P}}$} $250 \mathrm{kDa}=$ $75 \mathrm{kDa}-$

$50 \mathrm{kDa}-$

$37 \mathrm{kDa}-$

\section{$25 \mathrm{kDa}-$}

$20 \mathrm{kDa}-$

$15 \mathrm{kDa}-$ $10 \mathrm{kDa} r$

Rb-Af380

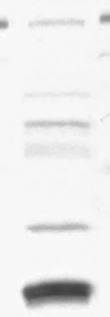

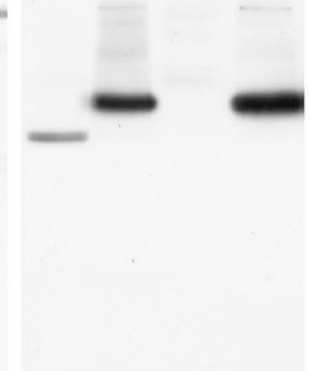

Go-Af450

Fig. 9 Anti- $\mathrm{CB}_{1}$ receptor immunohistochemical staining in sulphidefixed parietal cortex sections and Western blot analysis of P2 and $\mathrm{N}$ fractions from $\mathrm{CB}_{1}-\mathrm{WT}$ and $\mathrm{CB}_{1}-\mathrm{KO}$ mice generated by the Ledent's lab (Ledent et al. 1999) using the rabbit polyclonal Af380 and the goat polyclonal Af450 antibodies. a-f Micrographs showing the distribution of immunoreactivity produced by the Af380 antibody in the parietal cortex of $\mathrm{CB}_{1}-\mathrm{WT}(\mathbf{a}, \mathbf{c}, \mathbf{e})$ and $\mathrm{CB}_{1}-\mathrm{KO}(\mathbf{b}, \mathbf{d}, \mathbf{f})$ mice. Framed areas in panoramic images $\mathbf{a}$ and $\mathbf{b}$ are shown at higher magnification in $\mathbf{c}, \mathbf{d}$ and $\mathbf{e}, \mathbf{f}$ respectively. $\mathbf{g}-\mathbf{l}$ Micrographs showing the distribution of immunoreactivity produced by the Af450 antibody in the parietal cortex of $\mathrm{CB}_{1}-\mathrm{WT}(\mathbf{g}, \mathbf{i}, \mathbf{k})$ and $\mathrm{CB}_{1}-\mathrm{KO}(\mathbf{h}, \mathbf{j}, \mathbf{l})$ mice.
Framed areas in panoramic images $\mathbf{g}$ and $\mathbf{h}$ are shown at higher magnification in $\mathbf{i}-\mathbf{k}$ and $\mathbf{j}-\mathbf{l}$, respectively. $\mathbf{m}-\mathbf{n}$ Low-magnification micrographs showing the absence of immunostaining in the parietal cortex of $\mathrm{CB}_{1}-\mathrm{WT}(\mathbf{m})$ and $\mathrm{CB}_{1}-\mathrm{KO}(\mathbf{n})$ when Af450 antibody was used after being preabsorbed with the immunizing peptide. Scale bars: $200 \mu \mathrm{m}$ in $\mathbf{n}$ (applies to $\mathbf{a}, \mathbf{b}, \mathbf{g}, \mathbf{h}, \mathbf{m}, \mathbf{n}), 50 \mu \mathrm{m}$ in $\mathbf{l}$ (applies to $\mathbf{c}-\mathbf{f}, \mathbf{i}-\mathbf{l}$ ). o Western blot analysis of $\mathrm{P} 2$ and $\mathrm{N}$ fractions isolated from the adult mouse brain cortex of Ledent's $\mathrm{CB}_{1}-\mathrm{WT}$ and $\mathrm{CB}_{1}-\mathrm{KO}$ mice using either the Af380 (left immunoblot) or Go-Af380 (right immunoblot) antibodies. Double amount of protein was loaded from $\mathrm{CB}_{1}-\mathrm{KO}$ mice samples 
has been estimated to cause a mobility shift of about $4 \mathrm{kDa}$ on SDS-PAGE compared with non-truncated ones (Nordström and Andersson 2006). Therefore, considering the $1.2 \mathrm{kDa}$ size of the c-myc tag, it is expected that $\mathrm{CB}_{1}$ receptors are cleaved at around residue 26 of the $\mathrm{CB}_{1} \mathrm{~N}$-tail, probably resulting in the deletion of the N15 antibody epitope. Consequently, the N15 antibody would primarily recognize the newly synthesized $\mathrm{N}$-terminal tail of $\mathrm{CB}_{1}$ receptors prior to their translocation to the ER membrane via the secretory pathway used by most GPCRs lacking a cleavable signal peptide, with the first transmembrane domain of the mature receptor functioning as a signal anchor sequence (Wallin and Von Heijne 1995). In addition, N15 antibody could recognize incorrectly folded untruncated $\mathrm{CB}_{1}$ receptors retained and subjected to quality control in the ER as well as untruncated $\mathrm{CB}_{1}$ receptors that had passed ER quality control (Nordström and Andersson 2006). This is consistent with the observed immunostaining pattern of the N15 antibody, which was distributed mainly around the cell nucleus and showed a weak variable or no staining in the periphery and the plasma membrane of the transfected HEK-293 cells. The fact that the untruncated $\mathrm{CB}_{1}$ receptor probably represents only a small fraction of the entire population (Nordström and Andersson 2006) could explain the apparent low sensitivity of the N15 antibody, which in combination with markers of intracellular organelles could be very useful to study specific intracellular species of $\mathrm{CB}_{1}$ receptors. Indeed, retained GPCRs have been shown to display enhanced interaction with the ER luminal chaperone $\mathrm{BiP}$, as the primary regulator of endoplasmic reticulum translocation, as well as with carbohydrate-binding chaperones, which are key elements for recycling misfolded receptors through N-linked glycan recognition and processing (Moremen and Molinari 2006; Achour et al. 2008).

When tested on histological sections from the rat cerebral cortex, neither of the two $\mathrm{N}$-terminal antibodies produced a distribution pattern of $\mathrm{CB}_{1}$ receptor in fibres and presynaptic-like varicosities widely reported in previous studies (Egertová and Elphick 2000; Bodor et al. 2005; Deshmukh et al. 2007). Although this could be expected for the N15 antibody, it was surprising for the H150 antibody in view of the high specificity and sensitivity that it showed for detecting the $\mathrm{CB}_{1}$ receptor in HEK-293 cells. This contrasts with results obtained by other authors showing the ability of antibodies against large fragments of the amino end of $\mathrm{CB}_{1}$ receptor (Tsou et al. 1998; Eggan and Lewis 2007) or against a short 15 -amino-acid peptide far from the amino end of $\mathrm{CB}_{1}$ receptor (Dove Pettit et al. 1998), but not antibodies against a short 14-amino-acid peptide mapping at the extreme end of the $\mathrm{N}$-terminus (Mukhopadhyay and Howlett 2001; Matias et al. 2002), to produce immunohistochemical signals in brain tissue sections consistent with the accepted gross anatomical and fine distribution patterns for the $\mathrm{CB}_{1}$ receptor (Dove Pettit et al. 1998; Tsou et al. 1998; Eggan and Lewis 2007). Intriguingly, in one of the few studies devoted to the analysis of the specificity of anti$\mathrm{CB}_{1}$ antibodies (Grimsey et al. 2008), authors reported that two commercial antibodies produced against residues 1-77 (PA1-745, Affinity BioReagents) and 1-99 (C1108, SigmaAldrich) of the rat and human $\mathrm{CB}_{1}$ receptors, respectively, failed to detect the $\mathrm{CB}_{1}$ receptor in histological sections of rodent brain, not even in HEK-293 cells transfected with a HA-tagged human $\mathrm{CB}_{1}$ receptor, and neither in live cells nor in paraformaldehyde-fixed and permeabilized cells. In agreement with these negative results, other commercial antibody against rat $\mathrm{CB}_{1}$ receptor $\mathrm{N}$-terminal amino acids 1-77 (C1233, Sigma-Aldrich) and 1-99 (C1108, SigmaAldrich) produced immunohistochemical patterns in the cortex, striatum and hippocampus (Fusco et al. 2004) that were inconsistent with the widely accepted distribution of $\mathrm{CB}_{1}$ receptor. Differences in immunization and/or purification procedures relative to similar "homemade" antibodies could explain these discrepancies. Coming back to our present data, a possible reason for the lack of specificity of the H150 antibody in rat brain tissue sections could be that this antibody was generated using an immunogen corresponding to a sequence of human origin, since there are eight amino acid discrepancies between the human and rat $\mathrm{CB}_{1}$ receptor within a portion of the extracellular $\mathrm{N}$-tail encompassing residues $68-110$ and $68-111$ of human and rat proteins, respectively. A second possible explanation is that $\mathrm{N}$-linked glycans at asparagine residues 78 and 84 of the rat $\mathrm{CB}_{1}$ receptor (Song and Howlet 1995) could affect the recognition of the epitope by the H150 antibody, although this is unlikely since $\mathrm{N}$-glycosylation should have also affected epitope recognition in HEK-293 cells transfected with the human $\mathrm{CB}_{1}$ receptor, which is known to be extensively N-glycosylated (Nordström and Andersson 2006; Ruehle et al. 2017).

Again, N15 and $\mathrm{H} 150$ antibodies did not detect $\mathrm{CB}_{1}$ receptors under denaturing conditions by SDS-PAGE and immunoblotting, as concluded from the analysis of the molecular mass of the immunoreactive bands (both antibodies), antibody-antigen preadsorption control (N15) and the presence of immunoreactive bands of identical size in the fractions of the rat cerebral showing (P1 and P2) and lacking (Cyt) $\mathrm{CB}_{1}$ receptor-specific ligand binding sites and $\mathrm{CB}_{1}$ receptor coupling to $G_{\mathrm{i} / \mathrm{o}}$ proteins. Similar to what has been discussed about the inability of these N-terminal antibodies to detect the brain $\mathrm{CB}_{1}$ receptor by immunohistochemistry, the uselessness of N15 and H150 for Western blotting could also be due to the constitutive $\mathrm{N}$-terminal truncation of the $\mathrm{CB}_{1}$ receptor and to differences in the primary sequence between human versus rat $\mathrm{CB}_{1}$ receptor, respectively. Another possibility is that the large size of the immunogen used to generate the H150 antibody could 
contain conformational antigenic determinants that would no longer be detectable after denaturation.

Of the three C-terminal antibodies analysed here, the Af450 and Af380 antibodies, raised against 31 amino acids at the extreme carboxy-terminus of mouse $\mathrm{CB}_{1}$ receptor were by far the ones that provided the best results in all the final applications tested, although they were not exempt from some issues related to sample processing and end-use application. Double immunofluorescence assays demonstrated a virtual complete co-localization between Af450, and Af380-immunoreactivities, but more importantly, both antibodies produced intense immunoreactivity largely restricted to axonal fibres and presynaptic-like puncta with an excellent signal-to-noise relationship in rat brain cortical sections, and the signals were virtually abolished by peptide preadsorption. This is consistent with several studies that showed a similar $\mathrm{CB}_{1}$ immunoreactivity distribution profile using antibodies raised against $\mathrm{C}$-terminal end fragments of variable length, including peptides comprising the last 13 (Egertová and Elphick 2000), 15 (Bodor et al. 2005; Deshmukh et al. 2007; Eggan and Lewis 2007; Eggan et al. 2010) and 73 (Hájos et al. 2000; Wager-Miller et al. 2002; Harkany et al. 2003; Monory et al. 2006; Eggan and Lewis 2007) $\mathrm{C}$-terminal end residues, as well as a number of reports using Af380 (Lafourcade et al. 2007; Yoneda et al. 2013; Diniz et al. 2019; Fuerte-Hortigón et al. 2021) and Af450 (Yoneda et al. 2013; Rivera et al. 2015; Exposito-Alonso et al. 2020) antibodies in the rodent brain cortex. Moreover, both Af380 (Mateo et al. 2017) and Af450 (Lafourcade et al. 2007; Peñasco et al. 2020; Egaña-Huguet et al. 2021) antibodies have proven to be adequate to describe the ultrastructural distribution of $\mathrm{CB}_{1}$ receptors and have been validated for specificity in transgenic mice lacking $\mathrm{CB}_{1}$ receptor (HebertChatelain et al. 2014b; Remmers et al. 2017; GutiérrezRodríguez et al. 2018). Remarkably, it has been observed that preadsorption of an antibody generated against the 73 C-terminal residues of the $\mathrm{CB}_{1}$ receptor with a peptide that spans only the last 15 amino acids removed most but not all of the $\mathrm{CB}_{1}$-specific axonal labelling, indicating that the 15 residues at the $\mathrm{C}$-terminus of $\mathrm{CB}_{1}$ receptor contained most of the antigenic determinants (Eggan and Lewis 2007). This could explain why the K15 antibody against an unspecified sequence upstream of the last 15 residues was able to recognize the $\mathrm{CB}_{1}$ receptor under overexpression conditions in HEK-293, although with a low sensitivity that may not be sufficient to detect physiological levels in brain tissue.

It is well known that the fixation procedure used affects immunohistochemical staining, increasing or reducing specific and non-specific signals or masking antigens to a greater or lesser extent (Fritschy 2008). For instance, Egertová and colleagues reported that the use of Bouin's fixative for immunohistochemical staining of rodent brain sections with $\mathrm{C}$-terminally directed anti-CB $\mathrm{CB}_{1}$ antibodies abolishes the background staining that still remains when immunogen-preadsorbed antibodies were used in 4\% paraformaldehyde-fixed tissue (Egertová et al. 1998; Egertová and Elphick 2000) and preserves only specific immunostaining produced by the same antibodies as seen by comparing tissue sections from $\mathrm{CB}_{1}-\mathrm{WT}$ and $\mathrm{CB}_{1}-\mathrm{KO}$ mice (Egertová et al. 2003; Monory et al. 2006). In addition, certain fixation procedures can prevent epitope masking that occurs as a result of conformational changes in antigens caused by paraformaldehyde fixation. Here, we examined the immunohistochemical staining profile obtained with the different antibodies in histological sections of the adult rat cortex obtained from sulphide-fixed brains. Although this procedure was first developed to reveal zinc-rich terminals using Timm's staining method (Hassler and Söremark 1968; Sloviter 1982) and, more particularly, as a marker of hippocampal mossy fibre sprouting in animal models of epilepsy (Nadler et al. 1980) and human epilepsy (Sutula et al. 1989), it has been described as a good method to improve immunoreactivity without compromising the immunostaining profile of different proteins (Mitchell et al. 1993); compared with other antigen-retrieval methods, it offers an important advantage for our particular purposes. Specifically, we have previously shown that sulphide fixation improves immunofluorescence signal intensity for phospholipase $\mathrm{C}$ beta 1 (PLC $\beta 1$ ) (Montaña et al. 2012) and diacylglycerol lipase $\alpha$ (DAGL $\alpha$ ) (García del Caño et al. 2015) and allows their detection in subcellular compartments where they do not appear stained or do so very weakly after standard fixation. Moreover, sulphide fixation did not affect the immunostaining profile of various GABAergic neuronal phenotype markers and glial markers (Montaña et al. 2012) and even increased the immunostaining intensity of subcellular markers such as lamin B1 (García del Caño et al. 2015). Thus, enhancement or maintenance of $\mathrm{CB}_{1}$ receptor immunoreactivity after sulphide fixation could allow simultaneous immunostaining of $\mathrm{CB}_{1}$ with key components of the brain endocannabinoid system such as PLC $\beta 1$ and DAGL $\alpha$, which are key enzymes for on-demand the synthesis (Shonesy et al. 2015) of the most abundant endogenous $\mathrm{CB}_{1}$ agonist (Stella et al. 1997) 2-arachidonoylglycerol (2-AG), as well as with phenotype and subcellular markers. Sulphide fixation did not rescue $\mathrm{CB}_{1}$-specific immunolabelling with N15, H150 and K15 antibodies, whereas it increased $\mathrm{CB}_{1}$-immunoreactivity with Af380 antibody and led to the emergence of a nuclear staining with Af450 antibody (which was sensitive to peptide preadsorption) with no changes in typical axonal labelling. Interestingly, double immunofluorescence assays in intact nuclei ( $\mathrm{N}$ fraction) isolated from rat cerebral cortex lacking plasma membrane protein contaminants revealed that the nuclear staining produced by anti-CB $\mathrm{CB}_{1}$ antibody overlapped with components of the nuclear matrix, similar to that previously observed for PLC $\beta 1$ and DAGL $\alpha$ (Montaña 
et al. 2012; García del Caño et al. 2014, 2015). In addition, Western blot analysis on isolated intact nuclei from rat cerebral cortex produced a clean and strong band at $\sim 60 \mathrm{kDa}$ that was sensitive to preadsorption of the antibody with the immunogen. Although this signal was clearly above the theoretical $52 \mathrm{kDa}$ molecular mass of the rat $\mathrm{CB}_{1}$ receptor, suggesting that it was not related to the $\mathrm{CB}_{1}$ receptor, other authors have interpreted the slower migration of these bands on SDS-PAGE as a consequence of N-linked glycosylation at the N-terminal region of $\mathrm{CB}_{1}$ receptor (Song and Howlett 1995; Egertová and Elphick 2000; De Jesús et al. 2006). Because such post-translational modifications could lead to a slower mobility of $\mathrm{CB}_{1}$ receptors on SDS-PAGE, our findings in intact nuclei still left open the unlikely but feasible and attractive possibility that the signal found in nuclei of neuronal cells with the Af450 antibody could be specific. However, neither specific $\mathrm{CB}_{1}$ receptor binding sites nor $\mathrm{CB}_{1}$ receptor coupling to inhibitory $\mathrm{G}$ proteins could be detected in intact nuclei samples by saturation radioligand binding assays and agonist-stimulated $\left[{ }^{35} \mathrm{~S}\right] \mathrm{GTP} \gamma \mathrm{S}$ binding. In view of these surprising and apparently contradictory results, we performed immunohistochemical assays on cerebral cortex sections of sulphide-fixed brains from a $\mathrm{CB}_{1}$ - $\mathrm{KO}$ mouse line (Ledent et al., 1999). As expected, the Af450 antibody produced the typical fibre staining and presynaptic-like profiles in tissue sections from $\mathrm{CB}_{1}-\mathrm{WT}$ mice but not from $\mathrm{CB}_{1}-\mathrm{KO}$ littermates, whereas a strong nuclear signal was observed in both. Furthermore, Western blot analysis on $\mathrm{N}$ samples from $\mathrm{CB}_{1}$-WT and $\mathrm{CB}_{1}$-KO mice showed that Af450 detected the strong $\sim 60 \mathrm{kDa}$ band mentioned above in both genotypes, virtually demonstrating that the nuclear staining produced by the Af450 antibody was not related to the $\mathrm{CB}_{1}$ receptor. It is likely that the strong immunoreactivity in cell nuclei observed with the Af450 antibody in both sulphide-fixed tissue sections and $\mathrm{N}$ samples resolved by SDS-PAGE results from the binding of IgGs to a sequence of the same $\mathrm{CB}_{1}$ receptor-unrelated protein. If that was the case, the observed artefact, rather than be caused by the appearance of "false epitopes" as a consequence of chemical modifications due to sulphide fixation, would be produced by an unmasking effect of a site inaccessible in tissue fixed under standard conditions but for which the Af450 antibody has high affinity when the protein is denatured for Western blot, thus reinforcing our previous evidence showing that sulphide fixation is a good antigen-retrieval method (Montaña et al. 2012; García del Caño et al. 2015) for immunohistochemistry and, furthermore, compatible with electron microscopy (Danscher 1981). Specificity tests with the Af380 antibody in tissue sections of $\mathrm{CB}_{1}$-WT and $\mathrm{CB}_{1}$-KO littermates subjected to sulphide fixation revealed that, as we had observed in rat tissue sections, this antibody is highly sensitive and specific under these conditions and produced only negligible background staining in brain cortex sections of $\mathrm{CB}_{1}-\mathrm{KO}$ mice, which makes it the best option for use in combination with the immunostaining of antigens that are retrieved by sulphide fixation.

Transgenic animals in which the antigen of interest have been eliminated are considered to be the gold standard for validation of antibody specificity in immunohistochemistry (Saper and Sawchenko 2003; Saper 2005; Bordeaux et al. 2010). However, these models are not free from pitfalls, as exemplified in a recent study on the specificity of four antibodies raised against synthetic peptide sequences corresponding to different parts of the murine $\mathrm{CB}_{2}$ cannabinoid receptor (Zhang et al. 2019). In this study, two different $\mathrm{CB}_{2}-\mathrm{KO}$ models generated by homologous recombination that replaced genetic sequences near the $3^{\prime}$ (Zimmer et al. $1999)$ and $5^{\prime}$ ends $\left(\mathrm{CB}_{2}-\mathrm{KO}\right.$ strain from Deltagen Inc.) of mouse $C n r 2$ exon 3 (which contains the entire mouse $\mathrm{CB}_{2}$ receptor encoding region) with the neomycin gene were used. Results of this study indicated that the undeleted $\mathrm{Cnr} 2$ gene sequences still encodes mutant or truncated $\mathrm{CB}_{2}$ receptor proteins or fragments that could be detected by anti- $\mathrm{CB}_{2}$ antibodies. Of note, the strategy to generate the Ledent's $\mathrm{CB}_{1}-\mathrm{KO}$ line led to null allele that still contains the triplets of $C n r l$ gene coding for amino acids 235-473 (Ledent et al. 1999). Although Ledent's mice have been well characterized for the correct transgene insertion and on the basis of a variety of responses to drugs, functional responses and behavioural tests, the evidence in $\mathrm{CB}_{2}-\mathrm{KO}$ models discussed above makes feasible the possibility that a transcript containing the coding sequence for the immunizing peptides for Af380 and Af450 antibodies (residues $443-473$ of mouse $\mathrm{CB}_{1}$ receptor) could be still expressed in these animals. However, three primer pairs targeting either the deleted or the remaining sequences of the $\mathrm{Cnrl}$ gene in the Ledent's $\mathrm{CB}_{1}-\mathrm{KO}$ mouse were unable to amplify any specific mRNA in $\mathrm{CB}_{1}-\mathrm{KO}$ samples by RT-PCR, whereas all the three probes detected $\mathrm{CB}_{1}$-specific mRNA sequences in $\mathrm{CB}_{1}$-WT littermates. To our knowledge, this is the first time that the possibility that transcripts containing sequences encoding anti- $\mathrm{CB}_{1}$ antibody epitopes may still be expressed in Ledent's $\mathrm{CB}_{1}-\mathrm{KO}$ mice has been addressed. Finally, immunohistochemical staining in histological sections of the cerebral cortex of $\mathrm{CB}_{1}-\mathrm{KO}$ mice in which the entire coding region of the Cnrl gene was eliminated (Marsicano et al. 2002) cleared up any doubt, since the Af380 and Af450 antibodies produced specific and non-specific signals identical to those observed in Ledent's $\mathrm{CB}_{1}-\mathrm{KO}$ mice, ruling out any possibility that the nuclear staining observed in Ledent's $\mathrm{CB}_{1}-\mathrm{KO}$ mice could be due to the presence of $\mathrm{CB}_{1}$ receptor protein fragments.

Of the three C-terminal antibodies used, the K15 antibody failed to detect $\mathrm{CB}_{1}$ receptor-specific signals by Western blot, since it produced immunoreactive bands in the $\mathrm{P} 1$ and $\mathrm{P} 2$ fractions that migrated clearly above the theoretical $52 \mathrm{kDa}$ molecular mass of rat $\mathrm{CB}_{1}$ receptor, which in 
addition were not eliminated by preadsorption of antibodies with an excess of the immunizing peptide. As discussed in relation to the futility of this antibody for immunohistochemical detection of the $\mathrm{CB}_{1}$ receptor, the inability of the $\mathrm{K} 15$ antibody to detect $\mathrm{CB}_{1}$ under denaturing conditions could be due to the fact that most of the antigenic determinants of the $\mathrm{C}$-terminal end of the $\mathrm{CB}_{1}$ receptor are located downstream of the antigen used. By contrast, both Af380 and Af450 antibodies were shown to detect a major band migrating slightly below the theoretical $52 \mathrm{kDa}$ molecular mass of rat $\mathrm{CB}_{1}$ only in $\mathrm{P} 1$ and $\mathrm{P} 2$, which contained $\mathrm{CB}_{1}$ receptor-specific binding sites and displayed agonist-stimulated $\mathrm{CB}_{1}$ receptor coupling to $G_{\mathrm{i} / \mathrm{o}}$ proteins as shown by saturation radioligand binding and agonist-stimulated $\left[{ }^{35} \mathrm{~S}\right]$ GTP $\gamma \mathrm{S}$ binding assays and, in addition, this $\sim 50 \mathrm{kDa}$ band was undetectable when the antibodies were preabsorbed with the immunizing peptide. Af380 antibody detected several other, weaker but clear bands with considerably higher and lower molecular weight in P1 and P2 fractions, whereas extra bands were faint or undetectable with Af450 antibody. The molecular weight of the $\sim 50 \mathrm{kDa}$ specific band detected by Western blot in our study agrees with previous reports using the same rabbit Af380 (Fukudome et al. 2004; Yoneda et al. 2013; Rodríguez-Cueto et al. 2016) and goat polyclonal Af450 (Yoneda et al. 2013) antibodies, including two studies from our lab (Peñasco et al. 2020; Egaña-Huguet et al. 2021). Despite the consistency of our data, results obtained by other authors reporting the detection of a major band of about $60 \mathrm{kDa}$ or higher using different anti-CB $\mathrm{CB}_{1}$ receptor antibodies deserve consideration (Song and Howlett 1995; Egertová and Elphick 2000; Mukhopadhyay and Howlett 2001; Wager-Miller et al. 2002; De Jesús et al. 2006; Diniz et al. 2019). Although this slower mobility has been explained as a result of glycosylation of the $\mathrm{CB}_{1}$ terminal tail (Song and Howlett 1995; Egertová and Elphick 2000; De Jesús et al. 2006), deglycosylation experiments cause also a considerably mobility shift of the $\sim 50 \mathrm{kDa}$ detected with antibodies against large fragments of the $\mathrm{N}$-terminal region or the C-terminal end of $\mathrm{CB}_{1}$ receptor (Nordström and Andersson 2006; Esteban et al. 2020), and therefore, these discrepancies must be due to other factors. On the one hand, the antibodies used in some cases were raised against a small fragment of the amino terminal end of the $\mathrm{CB}_{1}$ receptor (Song and Howlett 1995; Mukhopadhyay and Howlett 2001), and as discussed extensively above, it is possible that truncation of a short $\mathrm{N}$-terminal fragment of the $\mathrm{CB}_{1}$ receptor in the early stages of maturation could cause these antibodies to recognize only untruncated $\mathrm{CB}_{1}$ receptors of higher molecular weight, which appear to represent a small fraction of the total receptor population (Nordström and Andersson 2006). On the other hand, heating samples at high temperature causes $\mathrm{CB}_{1}$ receptor aggregates with considerably lower mobility in SDS-PAGE (Wager-Miller and Mackie 2016), and it has been recently reported that temperatures above $65{ }^{\circ} \mathrm{C}$ favour the formation of highmolecular-weight aggregates (Esteban et al. 2020), which could explain the high-molecular-weight bands migrating considerably above $60 \mathrm{kDa}$ described before (Matias et al. 2002; Wager-Miller et al. 2002). Among the studies focused on the specificity of anti-CB $\mathrm{CB}_{1}$ antibodies intended for Western blotting, it is worth highlighting a recent work devoted to the analysis of the mobility of the $\mathrm{CB}_{1}$ receptor on SDSPAGE using different $\mathrm{N}$-terminal and $\mathrm{C}$-terminal antibodies and $\mathrm{CB}_{1}-\mathrm{KO}$ mice as negative control (Esteban et al. 2020). Noteworthily, only one of the three antibodies used by these authors designed against the first 14 residues of the $\mathrm{N}$-terminal end of the $\mathrm{CB}_{1}$ receptor recognized a single $\mathrm{CB}_{1}$ receptor-specific band at $\sim 64 \mathrm{kDa}$, whereas two antibodies generated against the $\mathrm{C}$-terminal end of the $\mathrm{CB}_{1}$ receptor and one against residues 84-99 of the $\mathrm{N}$-terminal tail (and, therefore, far from the amino end of $\mathrm{CB}_{1}$ receptor) detected a single specific band at $\sim 50 \mathrm{kDa}$. Although the authors proposed an interpretation based on the folding and packing state of the protein and the detergent used, their data could be also interpreted as a result of the ability of antibodies against the $\mathrm{N}$-terminal end of the $\mathrm{CB}_{1}$ receptor to recognize solely a minor fraction of high-molecular-weight untruncated $\mathrm{CB}_{1}$ receptors, which would be below the detection threshold when antibodies are designed against peptides corresponding to sequences located far from the $\mathrm{N}$-terminal extreme. In favour of this interpretation, two of the three antibodies that recognized a specific band of $\sim 50 \mathrm{kDa}$ in mouse cerebral cortex and cerebellum could not detect the band of $\sim 64 \mathrm{kDa}$ in mouse brain immunoprecipitates prepared with the antibody against the end of the $\mathrm{N}$-tail of $\mathrm{CB}_{1}$ receptor, whereas they detected the $\sim 50 \mathrm{kDa}$ band in immunoprecipitates prepared with the other two antibodies, probably due to the extremely low density of the putatively untruncated $\sim 64 \mathrm{kDa}$ $\mathrm{CB}_{1}$ receptors compared to $\sim 50 \mathrm{kDa}$ species (Esteban et al. 2020). On the contrary, the antibody against the N-terminal end of the $\mathrm{CB}_{1}$ receptor produced a single band at $\sim 64 \mathrm{kDa}$ of the same intensity regardless of the antibody used for immunoprecipitation, strongly suggesting that this antibody detects with high sensitivity a minor species of the untruncated receptor. In any case, the results described by Esteban and colleagues (2020) using anti- $\mathrm{CB}_{1}$ antibodies designed either against the $\mathrm{C}$-terminus or against residues 84-99 of the N-tail of the $\mathrm{CB}_{1}$ receptor are in good agreement with our finding that both Af380 and Af450 recognize a unique $\mathrm{CB}_{1}$ receptor-specific band migrating at $\sim 50 \mathrm{kDa}$ on SDS-PAGE as seen by analysing immunoreactive bands in $\mathrm{P} 2$ membranes from the cerebral cortex of $\mathrm{CB}_{1}-\mathrm{WT}$ and $\mathrm{CB}_{1}$-KO littermates. The use of $\mathrm{CB}_{1}-\mathrm{KO}$ animals as negative controls also allowed us to establish Af450 antibody as the best choice for Western blot assays in cortical P2 membranes, since Af380 antibody produced a number of 
non-specific bands of variable intensity and migrating above and below the $\sim 50 \mathrm{kDa} \mathrm{CB}{ }_{1}$ receptor-specific band, whereas Af450 led to a single $\sim 50 \mathrm{kDa}$ specific band.

In conclusion, of the five antibodies tested for specificity, three of them were identified as the best choice for specific end-use applications. Thus, the ability of the H150 antibody to detect surface receptors in HEK-293 cells overexpressing $\mathrm{CB}_{1}$ receptors makes it an excellent unique tool of particular interest to study the dynamics of processes such as internalization, recycling or trafficking to the plasma membrane of $\mathrm{CB}_{1}$ receptors. Antibodies Af 380 and Af 450 provided excellent results for immunodetection of $\mathrm{CB}_{1}$ receptors in permeabilized HEK-293 cells and in fixed brain tissue, although only the Af380 antibody is suitable under sulphide fixation when this method is used to increase immunoreactivity for other antigens such as components of the endocannabinoid system or cell phenotype markers. Both Af380 and Af450 antibodies are useful for detection of $\mathrm{CB}_{1}$ receptor by Western blot, although the Af380 antibody detects several non-specific bands while Af450 does not, making the latter option the best for Western blot analysis. Our results further highlight the need for a F4P approach for validation of antibodies before they are placed on the market or discontinued, and we urge suppliers to leave final validation of antibodies for specific end uses to basic researchers.

Supplementary Information The online version contains supplementary material available at https://doi.org/10.1007/s00418-021-02025-5.

Acknowledgements The authors thank Giovanni Marsicano (INSERM U1215, NeuroCentre Magendie, Bordeaux, France) for kindly supplying $\mathrm{CB}_{1}-\mathrm{KO}$ mice. The authors wish to thank Ricardo Andrade (Servicio de Microscopía Analítica y de Alta Resolución en Biomedicina, SGIker) for skilful technical assistance with confocal microscopy experiments. Joan Sallés is a member of the Societat Catalana de Biologia, a subsidiary society of the Institut d' Estudis Catalans (Barcelona, Catalonia).

Author contributions L.E. and G.G.C. contributed equally to experimental work.

Funding Open Access funding provided thanks to the CRUE-CSIC agreement with Springer Nature. This work was funded by Basque Government (IT1230-19, to J.S.), MINECO CTQ2017-85686-R (Spanish Ministry of Economy and Competitiveness, to J.S. and M.A.G.), FEDER and ISCIII (AES 2018-PI18/00513, to S.M.), MINECO SAF2016-75292-R MINECO, to C.M.) and Centro de Investigación Biomédica en Red de Salud Mental (CIBERSAM, to J.S. and S.B.).

Data availability The authors confirm that the data supporting the findings of this study are available within the article and the associated Electronic supplementary material.

\section{Declarations}

Conflict of interest The authors have no conflict of interests to declare.
Ethical approval All experiments involving animals were approved by the Committee of Ethics for Animal Welfare of the University of the Basque Country (UPV/EHU; CEBA/146/2010 and CEBA/61/2010) and performed following guidelines of the Directive of the European Commission (2010/63/EU) and Spanish regulations (RD 53/2013) for care and management of experimental animals.

Open Access This article is licensed under a Creative Commons Attribution 4.0 International License, which permits use, sharing, adaptation, distribution and reproduction in any medium or format, as long as you give appropriate credit to the original author(s) and the source, provide a link to the Creative Commons licence, and indicate if changes were made. The images or other third party material in this article are included in the article's Creative Commons licence, unless indicated otherwise in a credit line to the material. If material is not included in the article's Creative Commons licence and your intended use is not permitted by statutory regulation or exceeds the permitted use, you will need to obtain permission directly from the copyright holder. To view a copy of this licence, visit http://creativecommons.org/licenses/by/4.0/.

\section{References}

Achour L, Labbé-Jullié C, Scott MGH, Marullo S (2008) An escort for GPCRs: implications for regulation of receptor density at the cell surface. Trends Pharmacol Sci 29:528-535. https://doi.org/ 10.1016/j.tips.2008.07.009

An D, Peigneur S, Hendrickx LA, Tytgat J (2020) Targeting cannabinoid receptors: current status and prospects of natural products. Int J Mol Sci 21:1-33. https://doi.org/10.3390/ijms21145064

Andersson H, D'Antona AM, Kendall DA et al (2003) Membrane assembly of the cannabinoid receptor 1 : impact of a long N-terminal tail. Mol Pharmacol 64:570-577. https://doi.org/10.1124/ mol.64.3.570

Baker M (2015) Blame it on the antibodies. Nature 521:274-276. https://doi.org/10.1038/521274a

Barrondo S, Sallés J (2009) Allosteric modulation of 5-HT1A receptors by zinc: binding studies. Neuropharmacology 56:455-462. https://doi.org/10.1016/j.neuropharm.2008.09.018

Bodor ÁL, Katona I, Nyíri G et al (2005) Endocannabinoid signaling in rat somatosensory cortex: laminar differences and involvement of specific interneuron types. J Neurosci 25:6845-6856. https:// doi.org/10.1523/JNEUROSCI.0442-05.2005

Bordeaux J, Welsh AW, Agarwal S et al (2010) Antibody validation. Biotechniques 48:197-209. https://doi.org/10.2144/000113382

Busquets-Garcia A, Bains J, Marsicano G (2018) CB 1 receptor signaling in the brain: extracting specificity from ubiquity. Neuropsychopharmacology 43:4-20. https://doi.org/10.1038/npp.2017.206

Casadó V, Barrondo S, Spasic M et al (2010) Gi protein coupling to adenosine A1-A2A receptor heteromers in human brain caudate nucleus. J Neurochem 114:972-980. https://doi.org/10.1111/j. 1471-4159.2010.06810.x

Chicca A, Nicolussi S, Bartholomäus R et al (2017) Chemical probes to potently and selectively inhibit endocannabinoid cellular reuptake. Proc Natl Acad Sci U S A 114:E5006-E5015. https://doi. org/10.1073/pnas.1704065114

Christopoulos A (1998) Assessing the distribution of parameters in models of ligand-receptor interaction: to log or not to log. Trends Pharmacol Sci 19:351-357. https://doi.org/10.1016/S01656147(98)01240-1

Cinar R, Iyer MR, Kunos G (2020) The therapeutic potential of second and third generation CB1R antagonists. Pharmacol Ther 208:107477. https://doi.org/10.1016/j.pharmthera.2020.107477 
Cristino L, Bisogno T, Di Marzo V (2020) Cannabinoids and the expanded endocannabinoid system in neurological disorders. Nat Rev Neurol 16:9-29. https://doi.org/10.1038/s41582-019-0284-z

Danscher G (1981) Light and electron microscopic localization of silver in biological tissue. Histochemistry 71:177-186. https://doi. org/10.1007/BF00507822

De Jesús ML, Sallés J, Meana JJ, Callado LF (2006) Characterization of $\mathrm{CB} 1$ cannabinoid receptor immunoreactivity in postmortem human brain homogenates. Neuroscience 140:635-643. https:// doi.org/10.1016/j.neuroscience.2006.02.024

Deshmukh S, Onozuka K, Bender KJ et al (2007) Postnatal development of cannabinoid receptor type 1 expression in rodent somatosensory cortex. Neuroscience 145:279-287. https://doi.org/10. 1016/j.neuroscience.2006.11.033

Di Marzo V (2018) New approaches and challenges to targeting the endocannabinoid system. Nat Rev Drug Discov 17:623-639. https://doi.org/10.1038/nrd.2018.115

Diniz CRAF, Biojone C, Joca SRL et al (2019) Dual mechanism of TRKB activation by anandamide through CB1 and TRPV1 receptors. Peer J 2019:1-21. https://doi.org/10.7717/peerj.6493

Dove Pettit DA, Harrison MP, Olson JM et al (1998) Immunohistochemical localization of the neural cannabinoid receptor in rat brain. J Neurosci Res 51:391-402. https://doi.org/10.1002/(SICI) 1097-4547(19980201)51:3\%3c391::AID-JNR12\%3e3.0.CO;2-A

Egaña-Huguet J, Bonilla-Del Río I, Gómez-Urquijo SM et al (2021) The absence of the transient receptor potential vanilloid 1 directly impacts on the expression and localization of the endocannabinoid system in the mouse hippocampus. Front Neuroanat 15:1-17. https://doi.org/10.3389/fnana.2021.645940

Egertová M, Cravatt BF, Elphick MR (2003) Comparative analysis of fatty acid amide hydrolase and $\mathrm{cb}(1)$ cannabinoid receptor expression in the mouse brain: evidence of a widespread role for fatty acid amide hydrolase in regulation of endocannabinoid signaling. Neuroscience 119:481-496. https://doi.org/10.1016/ s0306-4522(03)00145-3

Egertová M, Elphick MR (2000) Localisation of cannabinoid receptors in the rat brain using antibodies to the intracellular C-terminal tail of CB1. J Comp Neurol 422:159-171. https://doi.org/10. 1002/(SICI)1096-9861(20000626)422:2\%3c159::AID-CNE1\% 3e3.0.CO;2-1

Egertová M, Giang DK, Cravatt BF, Elphick MR (1998) A new perspective on cannabinoid signalling: complementary localization of fatty acid amide hydrolase and the CB1 receptor in rat brain. Proc Biol Sci 265:2081-2085. https://doi.org/10.1098/rspb.1998. 0543

Eggan SM, Lewis DA (2007) Immunocytochemical distribution of the cannabinoid CB1 receptor in the primate neocortex: a regional and laminar analysis. Cereb Cortex 17:175-191. https://doi.org/ 10.1093/cercor/bhj136

Eggan SM, Mizoguchi Y, Stoyak SR, Lewis DA (2010) Development of cannabinoid 1 receptor protein and messenger RNA in monkey dorsolateral prefrontal cortex. Cereb Cortex 20:1164-1174. https://doi.org/10.1093/cercor/bhp179

Esteban PF, Garcia-Ovejero D, Paniagua-Torija B et al (2020) Revisiting CB1 cannabinoid receptor detection and the exploration of its interacting partners. J Neurosci Methods 337:108680. https:// doi.org/10.1016/j.jneumeth.2020.108680

Exposito-Alonso D, Osório C, Bernard C et al (2020) Subcellular sorting of neuregulins controls the assembly of excitatory-inhibitory cortical circuits. eLife 9:1-28. https://doi.org/10.7554/eLife. 57000

Fernández-Ruiz J, Galve-Roperh I, Sagredo O, Guzmán M (2020) Possible therapeutic applications of cannabis in the neuropsychopharmacology field. Eur Neuropsychopharmacol 36:217-234. https://doi.org/10.1016/j.euroneuro.2020.01.013
Fritschy JM (2008) Is my antibody-staining specific? How to deal with pitfalls of immunohistochemistry. Eur J Neurosci 28:2365-2370. https://doi.org/10.1111/j.1460-9568.2008.06552.x

Fuerte-Hortigón A, Gonçalves J, Zeballos L et al (2021) Distribution of the cannabinoid receptor type 1 in the brain of the genetically audiogenic seizure-prone hamster GASH/sal. Front Behav Neurosci 15:1-20. https://doi.org/10.3389/fnbeh.2021.613798

Fukudome Y, Ohno-shosaku ÃT, Matsui ÃM et al (2004) Two distinct classes of muscarinic action on hippocampal inhibitory synapses. Eur J Neurosci 19:2682-2692. https://doi.org/10.1111/j.14609568.2004.03384.x

Fusco FR, Martorana A, Giampà C et al (2004) Immunolocalization of CB1 receptor in rat striatal neurons: a confocal microscopy study. Synapse 53:159-167. https://doi.org/10.1002/syn.20047

García del Caño G, Aretxabala X, González-Burguera I et al (2015) Nuclear diacylglycerol lipase- $\alpha$ in rat brain cortical neurons: evidence of 2-arachidonoylglycerol production in concert with phospholipase C- $\beta$ activity. J Neurochem 132:489-503. https:// doi.org/10.1111/jnc. 12963

García del Caño G, Montaña M, Aretxabala X et al (2014) Nuclear phospholipase C- $\beta 1$ and diacylglycerol LIPASE- $\alpha$ in brain cortical neurons. Adv Biol Regul 54:12-23. https://doi.org/10.1016/j. jbior.2013.09.003

Garro MA, De Jesús ML, De Azúa IR et al (2001) Regulation of phospholipase $\mathrm{C} \beta$ activity by muscarinic acetylcholine and 5-HT2 receptors in crude and synaptosomal membranes from human cerebral cortex. Neuropharmacology 40:686-695. https://doi.org/10.1016/S0028-3908(00)00206-9

González-Maeso J, Rodríguez-Puertas R, Gabilondo AM, Meana JJ (2000) Characterization of receptor-mediated $\left[{ }^{35} \mathrm{~S}\right] \mathrm{GTP} \gamma \mathrm{S}$ binding to cortical membranes from postmortem human brain. Eur $\mathbf{J}$ Pharmacol 390:25-36. https://doi.org/10.1016/s0014-2999(99) 00827-4

Grimsey NL, Goodfellow CE, Scotter EL et al (2008) Specific detection of $\mathrm{CB} 1$ receptors; cannabinoid CB1 receptor antibodies are not all created equal! J Neurosci Methods 171:78-86. https://doi.org/10.1016/j.jneumeth.2008.02.014

Gutiérrez-Rodríguez A, Bonilla-Del Río I, Puente N et al (2018) Localization of the cannabinoid type-1 receptor in subcellular astrocyte compartments of mutant mouse hippocampus. Glia 66:1417-1431. https://doi.org/10.1002/glia.23314

Hájos N, Katona I, Naiem SS et al (2000) Cannabinoids inhibit hippocampal GABAergic transmission and network oscillations. Eur J Neurosci 12:3239-3249. https://doi.org/10.1046/j.14609568.2000.00217.x

Harkany T, Härtig W, Berghuis P et al (2003) Complementary distribution of type 1 cannabinoid receptors and vesicular glutamate transporter 3 in basal forebrain suggests input-specific retrograde signalling by cholinergic neurons. Eur J Neurosci 18:1979-1992. https://doi.org/10.1046/j.1460-9568.2003. 02898.x

Hassler O, Söremark R (1968) Accumulation of zinc in mouse brain. An autoradiographic study with 65Zn. Arch Neurol 19:117-120. https://doi.org/10.1001/archneur.1968.00480010135011

Hebert-Chatelain E, Reguero L, Puente N et al (2014a) Studying mitochondrial CB1 receptors: yes we can. Mol Metab 3:339. https:// doi.org/10.1016/j.molmet.2014.03.008

Hebert-Chatelain E, Reguero L, Puente N et al (2014b) Cannabinoid control of brain bioenergetics: exploring the subcellular localization of the CB1 receptor. Mol Metab 3:495-504. https://doi.org/ 10.1016/j.molmet.2014.03.007

Herkenham M (1991) Characterization and localization of cannabinoid receptors in brain: an in vitro technique using slide-mounted tissue sections. NIDA Res Monogr Ser 7:129-145 
Howlett AC, Barth F, Bonner TI et al (2002) International Union of Pharmacology. XXVII Classification of cannabinoid receptors. Pharmacol Rev 54:161-202. https://doi.org/10.1124/pr.54.2.161

Jositsch G, Papadakis T, Haberberger RV et al (2009) Suitability of muscarinic acetylcholine receptor antibodies for immunohistochemistry evaluated on tissue sections of receptor gene-deficient mice. Naunyn Schmiedebergs Arch Pharmacol 379:389-395. https://doi.org/10.1007/s00210-008-0365-9

Kano M, Ohno-Shosaku T, Hashimotodani Y et al (2009) Endocannabinoid-mediated control of synaptic transmission. Physiol Rev 89:309-380. https://doi.org/10.1152/physrev.00019.2008

Kirkpatrick P (2009) Specificity concerns with antibodies for receptor mapping. Nat Rev Drug Discov 8:278. https://doi.org/10.1038/ $\operatorname{nrd} 2854$

Lafourcade M, Elezgarai I, Mato S et al (2007) Molecular components and functions of the endocannabinoid system in mouse prefrontal cortex. PLoS ONE 2:1-11. https://doi.org/10.1371/journal.pone. 0000709

Ledent C, Valverde O, Cossu G et al (1999) Unresponsiveness to cannabinoids and reduced addictive effects of opiates in CB1 receptor knockout mice. Science 283:401-404. https://doi.org/ 10.1126/science.283.5400.401

López-Rodríguez ML, Vicente B, Deupi X et al (2002) Design, synthesis and pharmacological evaluation of 5-hydroxytryptamine(1a) receptor ligands to explore the three-dimensional structure of the receptor. Mol Pharmacol 62:15-21. https://doi.org/10.1124/ mol.62.1.15

Mailleux P, Vanderhaeghen JJ (1992) Distribution of neuronal cannabinoid receptor in the adult rat brain: a comparative receptor binding radioautography and in situ hybridization histochemistry. Neuroscience 48:655-668. https://doi.org/10.1016/03064522(92)90409-U

Maldonado R, Cabañero D, Martín-García E (2020) The endocannabinoid system in modulating fear, anxiety, and stress. Dialogues Clin Neurosci 22:229-239. https://doi.org/10.31887/ DCNS.2020.22.3/RMALDONADO

Marsicano G, Lutz B (1999) Expression of the cannabinoid receptor CB1 in distinct neuronal subpopulations in the adult mouse forebrain. Eur J Neurosci 11:4213-4225. https://doi.org/10. 1046/j.1460-9568.1999.00847.x

Marsicano G, Wotjak CT, Azad SC et al (2002) The endogenous cannabinoid system controls extinction of aversive memories. Nature 418:530-534. https://doi.org/10.1038/nature00839

Mateo Y, Johnson KA, Covey DP et al (2017) Endocannabinoid actions on cortical terminals orchestrate local modulation of dopamine release in the nucleus accumbens. Neuron 96:11121126.e5. https://doi.org/10.1016/j.neuron.2017.11.012

Matias I, Pochard P, Orlando P et al (2002) Presence and regulation of the endocannabinoid system in human dendritic cells. Eur J Biochem 269:3771-3778. https://doi.org/10.1046/j.1432-1033. 2002.03078.x

Matsuda LA, Bonner TI, Lolait SJ (1993) Localization of cannabinoid receptor mRNA in rat brain. J Comp Neurol 327:535-550. https://doi.org/10.1002/cne.903270406

McPartland JM, Glass M, Pertwee RG (2007) Meta-analysis of cannabinoid ligand binding affinity and receptor distribution: interspecies differences. Br J Pharmacol 152:583-593. https:// doi.org/10.1038/sj.bjp.0707399

Michel MC, Wieland T, Tsujimoto G (2009) How reliable are G-protein-coupled receptor antibodies? Naunyn Schmiedebergs Arch Pharmacol 379:385-388. https://doi.org/10.1007/ s00210-009-0395-y

Mitchell J, Best N, Sundstrom LE, Wheal HV (1993) The use of sodium sulphide-fixed brain tissue for immunocytochemical staining of activated microglia and reactive astrocytes. Histochemistry 99:91-94. https://doi.org/10.1007/BF00268026
Monory K, Massa F, Egertová M et al (2006) The endocannabinoid system controls key epileptogenic circuits in the hippocampus. Neuron 51:455-466. https://doi.org/10.1016/j.neuron.2006.07. 006

Montaña M, García del Caño G, López de Jesús M et al (2012) Cellular neurochemical characterization and subcellular localization of phospholipase $C \beta 1$ in rat brain. Neuroscience 222:239-268. https://doi.org/10.1016/j.neuroscience.2012.06.039

Moremen KW, Molinari M (2006) N-linked glycan recognition and processing: the molecular basis of endoplasmic reticulum quality control. Curr Opin Struct Biol 16:592-599. https://doi.org/10. 1016/j.sbi.2006.08.005

Mukhopadhyay S, Howlett AC (2001) CB1 receptor-G protein association: subtype selectivity is determined by distinct intracellular domains. Eur J Biochem 268:499-505. https://doi.org/10.1046/j. 1432-1327.2001.01810.x

Nadler JV, Perry BW, Cotman CW (1980) Selective reinnervation of hippocampal area CA1 and the fascia dentata after destruction of CA3-CA4 afferents with kainic acid. Brain Res 182:1-9. https:// doi.org/10.1016/0006-8993(80)90825-2

Nordström R, Andersson H (2006) Amino-terminal processing of the human cannabinoid receptor 1. J Recept Signal Transduct 26:259-267. https://doi.org/10.1080/10799890600758252

O'Connell TD, Swigart PM, Rodrigo MC et al (2006) Alpha1-adrenergic receptors prevent a maladaptive cardiac response to pressure overload. J Clin Invest 116:1005-1015. https://doi.org/10.1172/ JCI22811

Peñasco S, Rico-Barrio I, Puente N et al (2020) Intermittent ethanol exposure during adolescence impairs cannabinoid type 1 receptor-dependent long-term depression and recognition memory in adult mice. Neuropsychopharmacology 45:309-318. https://doi. org/10.1038/s41386-019-0530-5

Piomelli D (2003) The molecular logic of endocannabinoid signalling. Nat Rev Neurosci 4:873-884. https://doi.org/10.1038/nrn1247

Pradidarcheep W, Labruyère WT, Dabhoiwala NF, Lamers WH (2008) Lack of specificity of commercially available antisera: better specifications needed. J Histochem Cytochem 56:1099-1111. https://doi.org/10.1369/jhc.2008.952101

Puente N, Bonilla-Del Río I, Achicallende S et al (2019) High-resolution immunoelectron microscopy techniques for revealing distinct subcellular type 1 cannabinoid receptor domains in brain. Bio Protoc. https://doi.org/10.21769/bioprotoc.3145

Puighermanal E, Cutando L, Boubaker-Vitre J et al (2017) Anatomical and molecular characterization of dopamine D1 receptorexpressing neurons of the mouse CA1 dorsal hippocampus. Brain Struct Funct 222:1897-1911. https://doi.org/10.1007/ s00429-016-1314-x

Remmers F, Lange MD, Hamann M et al (2017) Addressing sufficiency of the $\mathrm{CB} 1$ receptor for endocannabinoid-mediated functions through conditional genetic rescue in forebrain GABAergic neurons. Brain Struct Funct 222:3431-3452. https://doi.org/10. 1007/s00429-017-1411-5

Rhodes KJ, Trimmer JS (2006) Antibodies as valuable neuroscience research tools versus reagents of mass distraction. J Neurosci 26:8017-8020. https://doi.org/10.1523/JNEUROSCI.2728-06. 2006

Rhomberg T, Rovira-Esteban L, Vikór A et al (2018) Vasoactive intestinal polypeptide-immunoreactive interneurons within circuits of the mouse basolateral amygdala. J Neurosci 38:6983-7003. https://doi.org/10.1523/JNEUROSCI.2063-17.2018

Rivera P, Bindila L, Pastor A et al (2015) Pharmacological blockade of the fatty acid amide hydrolase (FAAH) alters neural proliferation, apoptosis and gliosis in the rat hippocampus, hypothalamus and striatum in a negative energy context. Front Cell Neurosci 9:1-17. https://doi.org/10.3389/fncel.2015.00098 
Rodríguez-Cueto C, Hernández-Gálvez M, Hillard CJ et al (2016) Dysregulation of the endocannabinoid signaling system in the cerebellum and brainstem in a transgenic mouse model of spinocerebellar ataxia type-3. Neuroscience 339:191-209. https:// doi.org/10.1016/j.neuroscience.2016.09.046

Ruehle S, Wager-Miller J, Straiker A et al (2017) Discovery and characterization of two novel CB1 receptor splice variants with modified N-termini in mouse. J Neurochem 142:521-533. https://doi. org/10.1111/jnc. 14099

Ruiz de Azúa I, del Olmo E, Pazos A, Sallés J (2006) Transmembrane signaling through phospholipase C- $\beta$ in the developing human prefrontal cortex. J Neurosci Res 84:13-26. https://doi.org/10. 1002/jnr.20858

Sallés J, López de Jesús M, Goñi O et al (2001) Transmembrane signaling through phospholipase $\mathrm{C}$ in cortical and hippocampal membranes of psychogenetically selected rat lines. Psychopharmacology 154:115-125. https://doi.org/10.1007/s002130000621

Saper CB (2005) An open letter to our readers on the use of antibodies. J Comp Neurol 493:477-478. https://doi.org/10.1002/cne.20839

Saper CB, Sawchenko PE (2003) Magic peptides, magic antibodies: guidelines for appropriate controls for immunohistochemistry. $\mathrm{J}$ Comp Neurol 465:161-163. https://doi.org/10.1002/cne.10858

Shonesy BC, Winder DG, Patel S, Colbran RJ (2015) The initiation of synaptic 2-AG mobilization requires both an increased supply of diacylglycerol precursor and increased postsynaptic calcium. Neuropharmacology 91:57-62. https://doi.org/10.1016/j.neuro pharm.2014.11.026

Sloviter RS (1982) A simplified Timm stain procedure compatible with formaldehyde fixation and routine paraffin embedding of rat brain. Brain Res Bull 8:771-774. https://doi.org/10.1016/ 0361-9230(82)90104-6

Song C, Howlett AC (1995) Rat brain cannabinoid receptors are N-linked glycosylated proteins. Life Sci 56:1983-1989. https:// doi.org/10.1016/0024-3205(95)00179-A

Stella N, Schweitzer P, Plomelli D (1997) A second endogenous' cannabinoid that modulates long-term potentiation. Nature 388:773778. https://doi.org/10.1038/42015

Sutula T, Cascino G, Cavazos J et al (1989) Mossy fiber synaptic reorganization in the epileptic human temporal lobe. Ann Neurol 26:321-330. https://doi.org/10.1002/ana.410260303

Talmont F, Moulédous L, Boué J et al (2012) Denatured G-protein coupled receptors as immunogens to generate highly specific antibodies. PLoS ONE. https://doi.org/10.1371/journal.pone. 0046348

Thompson RJ (1973) Studies on RNA synthesis in two populations of nuclei from the mammalian cerebral cortex. J Neurochem 21:19-40. https://doi.org/10.1111/j.1471-4159.1973.tb04222.x
Tsou K, Brown S, Sañudo-Peña MC et al (1998) Immunohistochemical distribution of cannabinoid CB1 receptors in the rat central nervous system. Neuroscience 83:393-411. https://doi.org/10. 1016/S0306-4522(97)00436-3

Uchigashima M, Konno K, Demchak E et al (2020) Specific Neuroligin3- $\alpha$ Neurexin1 signaling regulates GABAergic synaptic function in mouse hippocampus. eLife 9:1-31. https://doi. org/10.7554/eLife.59545

Uhlen M, Bandrowski A, Carr S et al (2016) A proposal for validation of antibodies. Nat Methods 13:823-827. https://doi.org/10.1038/ nmeth.3995

Voskuil J (2014) Commercial antibodies and their validation. F1000Res 3:232. https://doi.org/10.12688/f1000research.4966.1

Voskuil JLA (2017) The challenges with the validation of research antibodies. F1000Res 6:1-9. https://doi.org/10.12688/f1000resea rch.10851.1

Wager-Miller J, Mackie K (2016) Western blotting of the endocannabinoid system. Methods Mol Biol 1412:247-254. https://doi. org/10.1007/978-1-4939-3539-0_25

Wager-Miller J, Westenbroek R, Mackie K (2002) Dimerization of $\mathrm{G}$ protein-coupled receptors: $\mathrm{CB} 1$ cannabinoid receptors as an example. Chem Phys Lipids 121:83-89. https://doi.org/10.1016/ S0009-3084(02)00151-2

Wallin E, Von Heijne G (1995) Properties of N-terminal tails in G-protein coupled receptors: a statistical study. Protein Eng Des Sel 8:693-698. https://doi.org/10.1093/protein/8.7.693

Yoneda T, Kameyama K, Esumi K et al (2013) Developmental and visual input-dependent regulation of the $\mathrm{CB} 1$ cannabinoid receptor in the mouse visual cortex. PLoS ONE. https://doi.org/10. 1371/journal.pone.0053082

Zhang H-Y, Shen H, Jordan CJ et al (2019) $\mathrm{CB}_{2}$ receptor antibody signal specificity: correlations with the use of partial $\mathrm{CB}_{2}$-knockout mice and anti-rat $\mathrm{CB}_{2}$ receptor antibodies. Acta Pharmacol Sin 40:398-409. https://doi.org/10.1038/s41401-018-0037-3

Zimmer A, Zimmer AM, Hohmann AG et al (1999) Increased mortality, hypoactivity, and hypoalgesia in cannabinoid CB1 receptor knockout mice. Proc Natl Acad Sci U S A 96:5780-5785. https:// doi.org/10.1073/pnas.96.10.5780

Publisher's Note Springer Nature remains neutral with regard to jurisdictional claims in published maps and institutional affiliations. 